
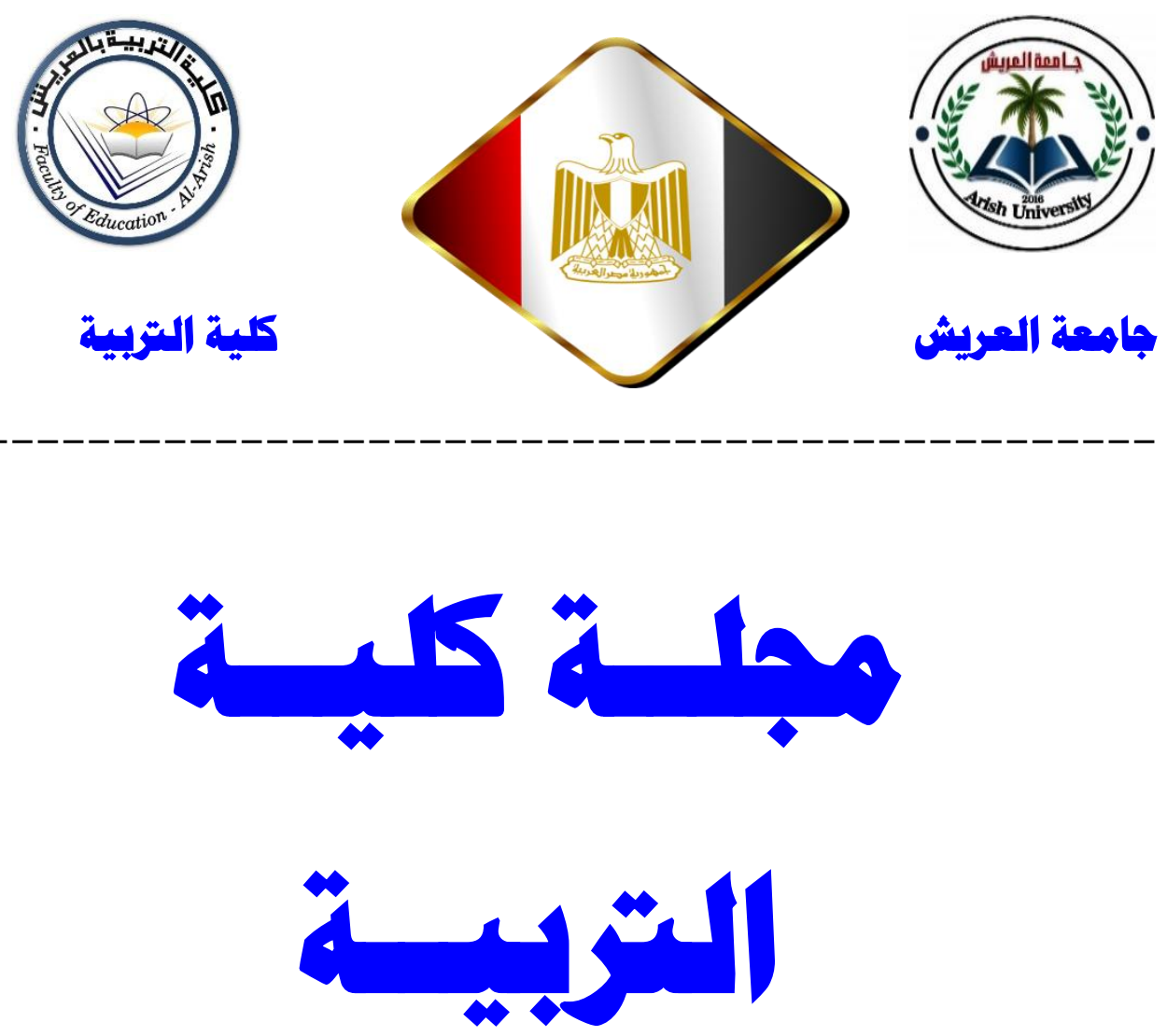

علمية محكمة ربع سنوية

(السنة السابعة - العدد الثامن عشر -إبريل 9 ( † م)

j_foea@aru.edu.eg 


\begin{tabular}{|c|c|}
\hline (رئيس مجـــ الكلية & أ.د. رفعت عمر عزوز \\
\hline وكيل الكلية للارراسات العليا والبحوث & أ.د. السيد كامل الشربيني \\
\hline
\end{tabular}

\section{هينئة التمريز}

\begin{tabular}{|c|c|}
\hline رئيس التحريز & أ.د. محمد رجب فضل الله \\
\hline مدير التحرير & أ.د. أحمد عبد العظيم سالم \\
\hline عضو & د. كمال طاهر موسىى \\
\hline عضو & د. أسماء حسن صبًاح \\
\hline
\end{tabular}

\section{الإشراف المالي والإداري}

\begin{tabular}{|l|l|}
\hline أ. أ. أسمداء محمد إهيم محمد عريبي المسؤول المالي الثاعر المسؤول الإداري \\
\hline أمير
\end{tabular}


ا ـ تتشر المجلة البحوث والدراسات التي تتوافر فيها الأصالة والمنهجية السليمة على ألا يكون البحث المقدم للنشر قد سبق وأن نشر، أو تم تقديمه للمراجعة والنشر لدى أي لاي جهة أخرى في نفس وقت تقديمه للمجلة. r. تُقبل الأبحاث المقدمة للنشر بإحدى اللغتين: العربية أو الإنجليزية.

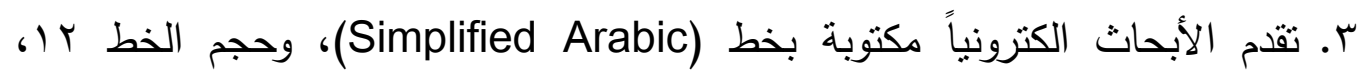
وهوامش حجم الواحد منها ه.بسم، مع مراعاة أن تتسق الفقرة بالتساوي ما بين الهامش الأيسر والأيمن (Justify). وترسل إلكترونياً على شكل ملف مراعن ( Microsoft) . (Word ع. يجب ألا يزيد عدد صفحات البحث الئحكم بما في ذلك الأشكال والرسوم والمراجع والجداول والملاحق عن (Y0) صفحة. (الزيادة بحد أقصى .1 صفحات برسوم

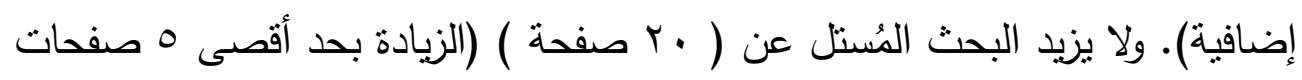

$$
\text { برسوم إضافية). }
$$

ه. يقدم الباحث ملخصاً لبحثه في صفحة واحدة، تتضمن الفقرة الأولى ملخصاً باللغة

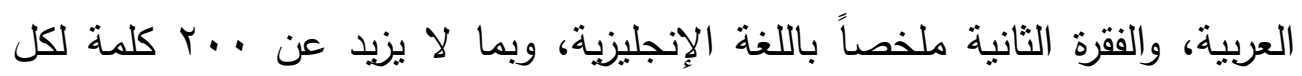

منها.

7. يكتب عنوان البحث واسم المؤلف والمؤسسة التي يعمل بها على صفحة منفصلة ثم يكتب عنوان البحث مرة أخرى على الصفحة الأولى من البحث. V. يجب عدم استخدام اسم الباحث في منن البحث أو قائمة المراجع ويتم استبدال الاسم

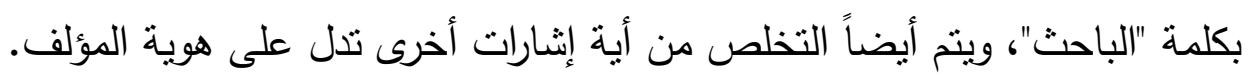

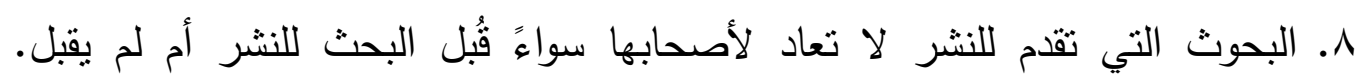
وتحتفظ هيئة التحرير بحقها في تحديد أولويات نشر البحوث.

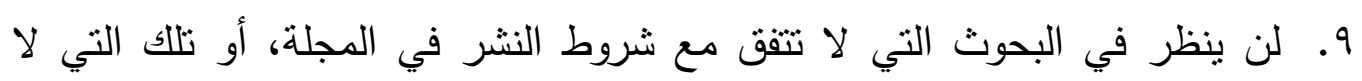

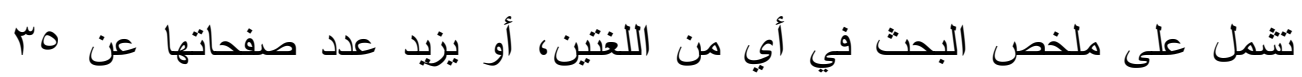

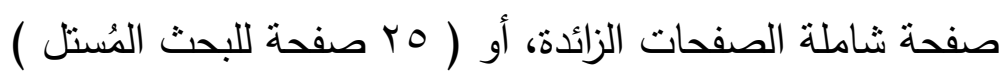
• 
11 (1 . يسهم الباحث في تكاليف نشر بحثه، ويتم تحويل التكلفة على الحساب الخاص بالمجلة. يجب إرسال صورة عن قسيمة التحويل أو دفع المبلغ، مع البحث الكترونيا.

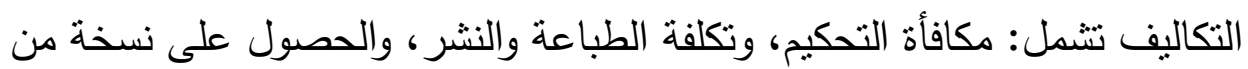

العدد، وعدد ( 0 ) مستلات من البحث المُحكم، و ( r ) من البحث المُستل. r ا. يتم نشر البحوث أو رفض نشرها في المجلة بناءً على تقارير المحكمين، ولا يسترد المبلغ في حالة رفض نشر البحث من قبل المحكمين. با. ـيُمنح كل باحث إفادة بقبول بحثه للنشر بعد إتمام كافة التصويبات والتعديلات المطلوبة، وسداد الرسوم المقررة.

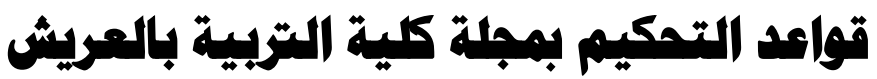

فيما يلي القواعد الأساسية لتحكيم البحوث المقدمة للنشر بمجلة كلية التربية بالعريش

\section{القواعد عامهة:}

ا ـ مدى ارتباط موضوع البحث بمجال التربية. r. مدى مناسبة الدراسات السابقة، وإبرازها لرؤى متعددة. r. درجة وضوح أسئلة وأهداف البحث. ع. مستوى تحديد عينة ومكان البحث.

ه. درجة إتباع البحث لمعايير التوثيق المحددة في دليل رابطة علم النفس الأمريكية، العدد السادس.

T. احتواء قائمة المراجع على جميع الدراسات المذكورة في منن البحث والعكس أيضاً صحيح.

V. حدود الدراسة، وتبريراتها. ^. سلامة نقرير البحث من الأخطاء اللغوية المتعلقة بالنحو والإملاء وكذا المعنى. 9. تكامل جميع أجزاء تقرير البحث، وترابطها بشكل منطقي.

قواعد الهكم على منهمية البمدث: ا . تحديد الفترة الزمنية للبحث. 
r. تحديد منهجية مناسبة للبحث.

r. تبرير إجراءات للاختيار في حالة دراسة الأفراد أو الجماعات. ع. تضمين البحث إطاراً نظرياً واضحاً.

ه. توضيح الإجراءات المتعلقة بالجوانب المهنية الأخلاقية مثل: الحصول على موافقة المشاركين المسبقة.

\section{قواعد تمكيم الإجراءات:}

ا. شرح وسائل جمع المعلومات بوضوح، والعمليات المنبعة فيها. r. تحديد وشرح المتغيرات المختلفة.

r. ترقيم جميع الجداول والأشكال والصور والرسوم البيانية بشكل مناسب وتبويبها والتأكد من سلامتها. ع. شرح عملية التحليل المتبعة ومبرراتها، والتأكد من اكتمالها وسلامتها.

\section{قواعد الهكم على النتانئه:}

ا. . عرض النتائج بوضوح.

r. توضيح جوانب الاختلاف في حالة تعارض نتائج البحث مع نتائج الدراسات السابقة. r. اتساق الخاتمة والتوصيات مع نتائج البحث. 


\section{محتويات العدد ( V )}

\begin{tabular}{|c|c|c|c|}
\hline \multicolumn{2}{|r|}{ هيئة التحرير } & \multicolumn{2}{|l|}{ السنة السابعة } \\
\hline الصفحات & 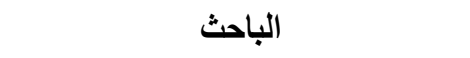 & عنوان البحث & 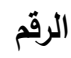 \\
\hline \multicolumn{4}{|c|}{ مقال العدد } \\
\hline $00-14$ & 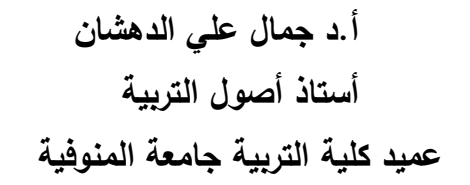 & انترنت الأشياء وتوظيفه في التعليم & 1 \\
\hline \multicolumn{4}{|c|}{ بحوث ودراسات محكمة } \\
\hline $11 \cdot-09$ & 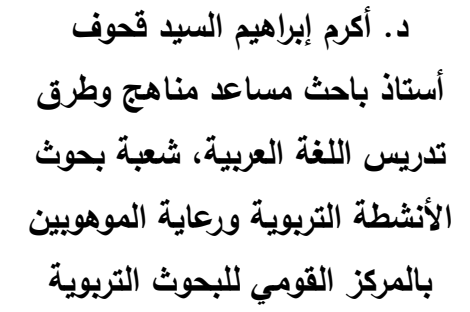 & 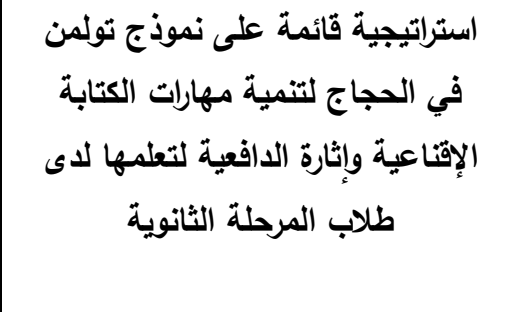 & 1 \\
\hline $100-111$ & 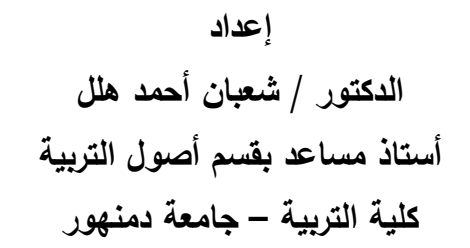 & الكراسي البحثية مدخلاً لتحقيق جودة & r \\
\hline \multicolumn{4}{|c|}{ بحوث مستلة من رسائل ماجستير ودكتوراه } \\
\hline$r .7-109$ & 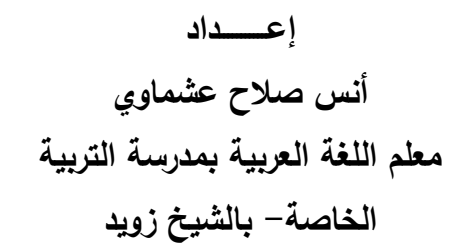 & الفعالية برنامج محوسب قائم على التعلم & 1 \\
\hline$r \leq r-r \cdot V$ & 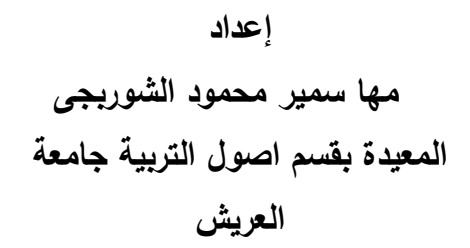 & دور قطاع خدمة المجتمع بجامعة قناة الثاني & $r$ \\
\hline$r q \leq-r \leqslant 0$ & باحثة ماجستير بقدم / مروة لطفي موسى عطية & فاعلية برنامج تعليمي إثرائي في تتمية & $r$ \\
\hline
\end{tabular}




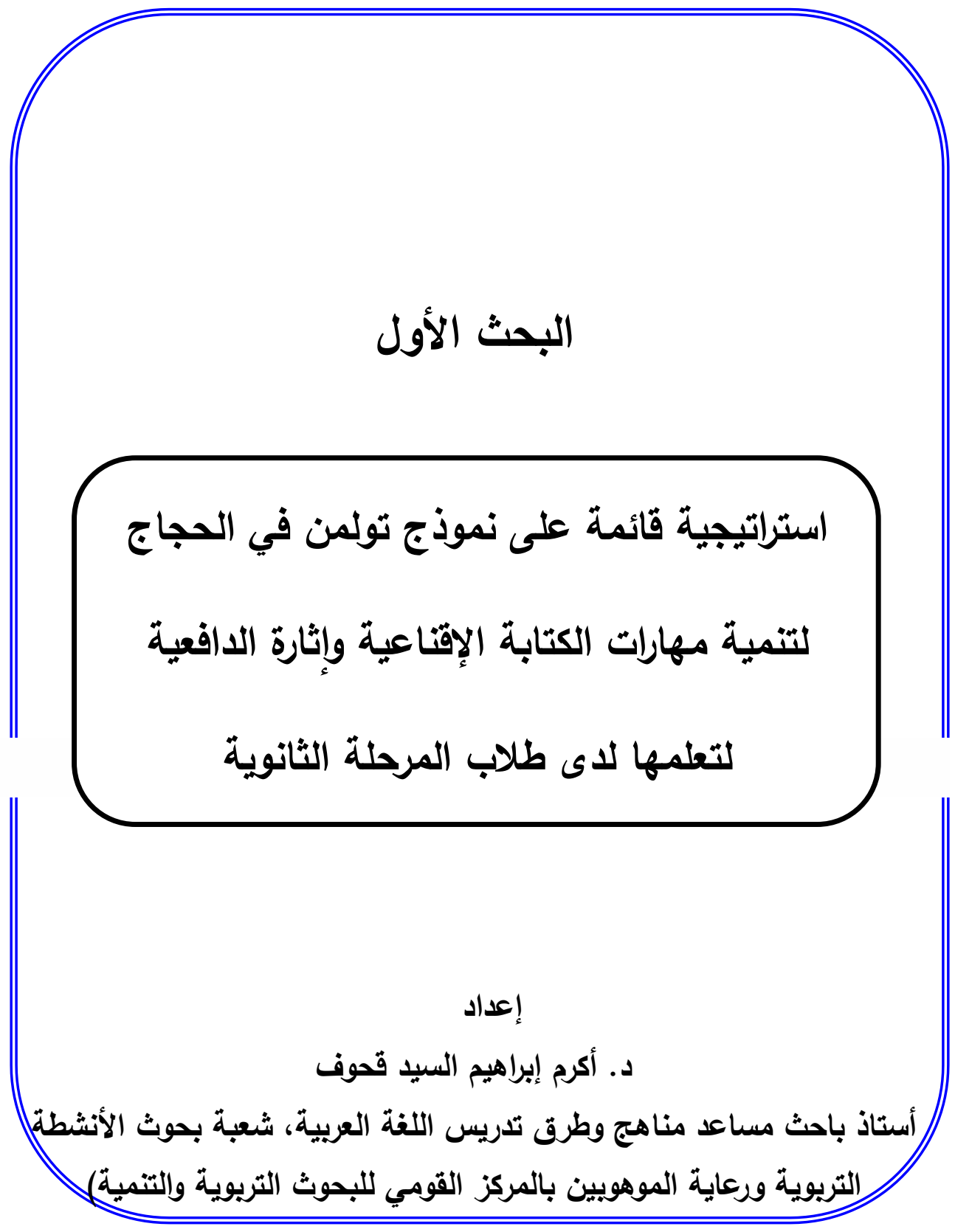




\section{استراتيجية قائمة على نموذج تولمن في الحجاج لتنمية مهارات}

الكتابة الإقتاعية وإثارة الدافعية لتعلمها لدى طلاب المرحلة الثانوية

إعداد/ د. أكرم إبراهيم السيد قحوف

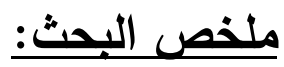

هدف البحث الحالي تعرف فاعلية استراتيجية قائمة على نموذج تولمن في الحجاج لتتمية مهارات الكتابة الإقناعية وإثارة الدافعية لتعلمها لدى طلاب المرحلة الثانوية، واعتمد البحث على المنهج شبه التجريبي؛ تصميم تجريبي ذي المجموعة الواحدة، عن

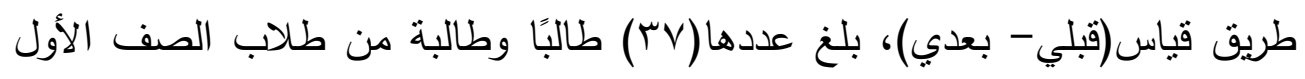
الثانوي. ولتحقيق هدف البحث تم إعداد قائمة مهارات الكتابة الإقناعية، واستراتيجية قائمة على نموذج نولمن في الحجاج، ودليل المعلم، ولقياس فاعلية الاستراتيجية في تتمية مهارات الكتابة الإقناعية وإثارة الدافعية لتعمها لدى طلاب الصف ودف الأول

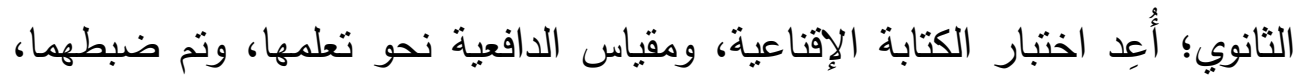
ووضعهما في صورة قابلة للتطبيق الميداني. وبتطبيق التجربة أظهرت النتائج أن للاستراتيجية فاعلية في تتمية مهارات الكتابة الإقناعية وإثارة الدافعية لتعلمها لدى طلاب المرحلة الثانوية. The current study aimed at identifying the effectiveness of a strategy based on Toulmin's Model of Argumentation on developing persuasive writing skills and stimulating motivation to be learned by secondary school students. The study adapted the quasi-experimental approach with pre-post test. The research sample consisted of two groups: the experimental group (37) and the control group (36). To achieve the goal of the research,

• أستاذ باحث مساعد مناهج وطرق تدريس اللغة العربية، شعبة بحوث الأنشطة التربوية

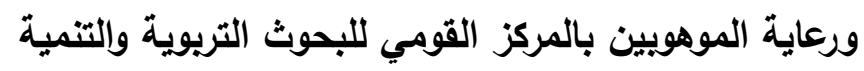


a list of persuasive writing skills, a strategy based on Toulmin's Model, and a teacher's guide were developed. To measure the effectiveness of the strategy on developing persuasive writing skills and motivation for first secondary school students, a measurement for persuasive writing and motivation towards it was prepared and validated to be applied.By administrating the experiment,. The results also indicated that there was strong correlation between improving persuasive writing skills and motivation to learn it by the experimental group students. This confirmed that the strategy was effective on improving the experimental group's persuasive writing and motivation to learn it by secondary school students. 
أولًا:(المقدمة:

الكتابة مُلتقى فنون اللغة، ووسيلة الطلاب للتواصل، والتعبير عن أفكارهم

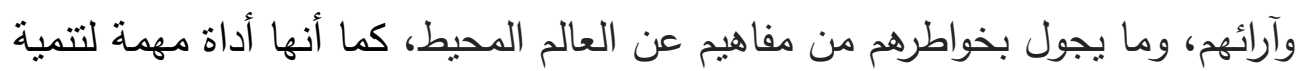
مهارات الإبداع والتفكير الناقد- والتي تعد بحسب الاتجاهات العالمية الحديثة- من المهارات الأساسية لمواكبة التطور والانفجار المعلوماتي في القرن الحادي والعشرين، والتي تسهم بشكل كبير في تعزيز النمو الأكاديمي في المجالات المعرفية المختلفة خاصة لدى طلاب المرحلة الثانوية، حيث إن الطلاب في هذه المرحلة يقتربون من مرحلة الشباب والنضج؛ مما يجعلهم أكثر انفتاحًا على العالم، وقضاياه المختلفة، ويشاركون بآرائهم في دعم الأفكار أو دحضها؛ فهم أكثر ميلًا للتفاعل مع مجتمعهم في شتى المجالات.

والكتابة الإقناعية نوع من أنواع الكتابة يحتاج إليها الطلاب بصفة عامة،

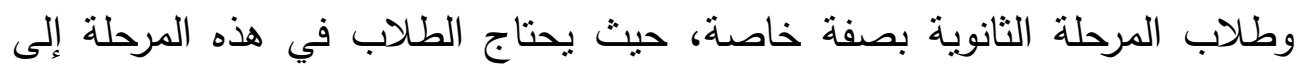
استخدام الكتابة الإقناعية من أجل التمكن من التعامل بفاعلية مع تحديات العصر، وأي نوع من أنواع المعلومات التي يأتي بها المستقبل؛ فالكتابة الإقناعية تمنل إحدى الإع لهن الأدوات المهمة التي تساعد الطلاب على إجراء المناقثات، وبناء الحجج، وتقديم الأدلة والبراهين في مختلف الموضوعات الجدلية التي قد تواجهم(حسن

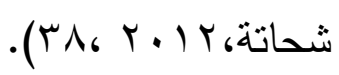

(Nippold, وفي هذا الصدد نؤكد دراسة كل من نيبولد ووارد لينرجان وفاينتج

M., Ward-Lonergan, J. \& Fanning, J. 2005) من المراحل المناسبة لتتمية مهارات الكتابة الإقناعية لدى طلابها؛ فهم يمتلكون مهارات عقلية فكرية تمكنهم من تحليل الموضوعات الجدلية، ومناقتتها، والبحث عن الأدلة، وحل المشكلات التي قد تواجههم باستخدام طرق وآليات محددة وواضحة؛ لإقناع الآخرين بوجهات النظر المختلفة، وهؤلاء الطلاب لديهم القدرة على الاستعانة بأساليب مقنعة في الكتابة بسوقون من خلالها الحجج، كما أن لديهم المرونة العقلية في التفكير بالمقارنة بالمتعلمين الأصغر سنًا في بقية المرحل الدراسية الأخرى. 
ولأن تتمية مهارات الكتابة الإقناعية مهمة لطلاب المرحلة الثانوية؛ فإن إثارة

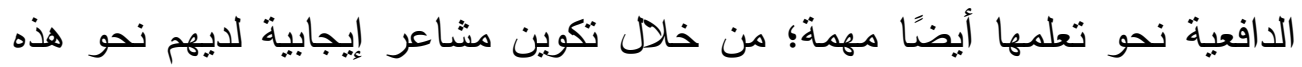

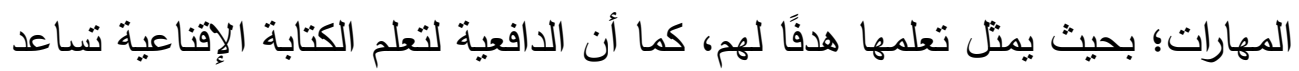
على تكوين الباعث الداخلي لدى هؤلاء الطلاب ، وتمكينهم من فرص التفاعل

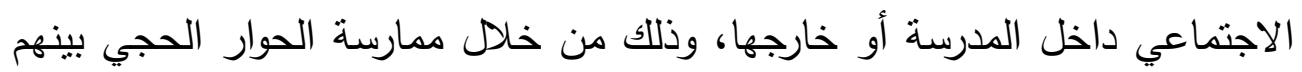
وبين الآخرين؛ فيعرفون الطرق اللازمة لنطوير تفكيرهم، كما تمكنهم كذلك من تقديم أفضل الوسائل لمناقشة مختلف الادعاءات، وتفكيك الخلافات، وحل المشكلات، ومن الن

$$
\text { ثم إنجاز الأهداف ( داليا يوسف محمد، • ( • ب، } 1 \text { • (1). }
$$

وترتبط الكتابة الإقناعية بالحجاج؛ ذلك أن الحجاج يعتمد على استخدام التعليل،

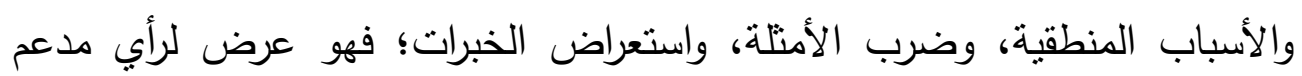

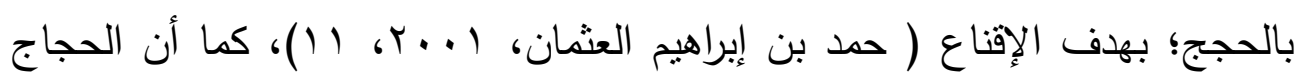
يتكون من أدلة تدعم فكرة ما أو ادعاء معين(Seyler, D., 2002)؛ فالحجاج هو بـإئ نشاط مهاري هادف، يتعلق باللغة الطبيعية، يعرض فيها المتكلم دعواه مدعومة

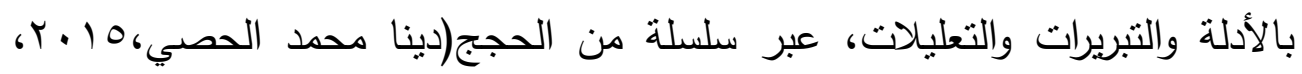
$\cdot(1 \leq$

وتعد نظرية الحجاج من بين النظريات الملائمة التي يمكن من خلالها تتمية

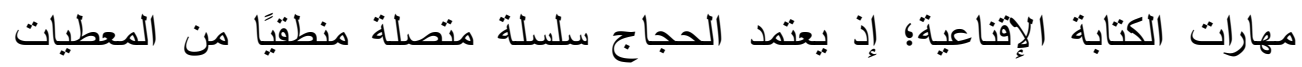
والبيانات والأدلة والأسباب والوقائع التي تُتخدم لدعم وجهة نظر معينة، أو فكرة محددة، أو أطروحة تُمثل الادعاء أو المطالبة، والغرض من هذا النوع من الحجاج هو لنو

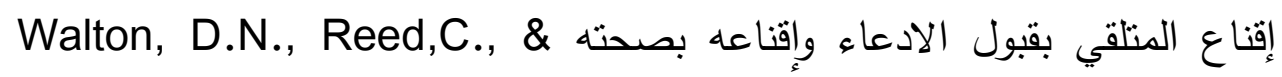
(Macagno,F.,2008)؛ فالحجاج وسيلة من وسائل الإقناع يتوسل بها المرسل للتأثير على المتلقي أو دحض آرائه أو حتى تغيير سلوكه، فبوساطة الحجج المُستخدمة في الحجاج ندرك شخصية هذين القطبين (المرسل، والمتلقي)، ومنزلتهما وإمكانتهما، وبالتالي يكون الحجاج توجيه خطاب إلى منلقٍ ما من أجل إقناعه بوجهة

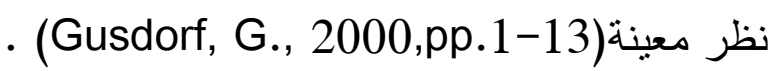


ونظرًا لأهمية تزويد الطلاب بالمهارات التي تمكنهم من التعبير عن آرائهم، لبناء شخصية واعية قادرة على التفكير الناقد وحل المشكلات بالقرن الحادي والعشرين - فإن الكتابة الإقناعية تأتي داعمًا مهمًا من دعائم تتميتها لديهم، وذلك من خلال تتمية قدراتهم على بناء الحجج التي تدعم لديهم المشاركة بنجاح في المناقثنات بشأن القضايا المجتمعية، والفحص الناقد لمصادر المعلومات المختلفة، وتعزيز مهارات

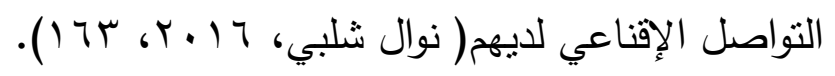

والمعروف أن من عناصر الكتابة الإقناعية بناء الحجج، وعرض الادعاءات حول القضايا الجدلية، أو تفنيد الآراء بطريقة منطقية، ودحض حجج الطرف الآخر بالأدلة والبراهين الاستدلالية والواقعية، وتقديم حجج لإقناع الطرف الآخر بوجهة النظر حول القضية( Nystrand, M. \& Graff, N.,2001,p.82) ونموذج تولمن في الحجاج؛ القائم على مجموعة من المراحل والخطوات، والإجراءات مهم في انخراط الطلاب في بناء الحجج، وهو نموذج يستتد إلى ستة عناصر هي: الإدعاء،

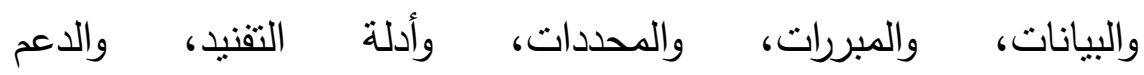

.(Tippett, C., 2009,PP.17-22)

ومعنى ذلك أن هناك نوافقًا كبيرًا بين هذا النموذج، وعناصر الكتابة الإقناعية،

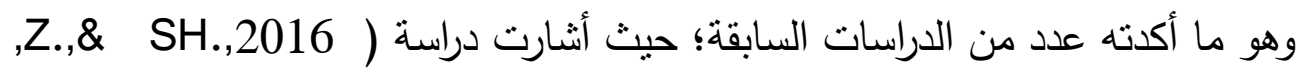
(Zainuddin Rafik-Galea., تتظيم أفكارهم، ومعلوماتهم، واستذلاتهم حول القضايا المختلفة التي يتحاجون حولها، وأثارت دراسة (10-10) Abdul Aziz,F.,\& Ahmad,U.,2107,pp.9) إلى أن نموذج تولمن في الحجاج يعطي الفرصة للطلاب لبناء ادعاءاتهم حول القضية المطروحة، فيتعلمون كيف يستخدمون أفكارهم؛ من أجل إقناع الآخرين بوجهة نظرهم. لذا؛ فإن الاستتاد إلى هذا النموذج في الحجاج قد يساعد في نمو مهارات

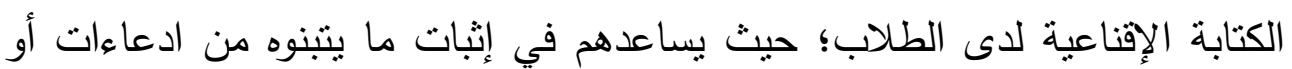
مطالبات مع من يختلف معهم في الرأي، أو تفنيد ما يعرض عليهم من حجج بطريقة منطقية، ودحض حجج الطرف الآخر بالأدلة والبراهين الاستدلالية والواقعية، وتقديم 
حجج لإقناع الطرف الآخر بها، حين يتحاجون حول قضية خلافية محددة، ويساعدهم

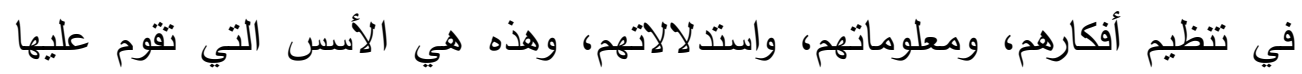
الكتابة الإقناعية.

\section{ثنانيًا: الإحساس بالمشكلة:}

وعلى الرغم من أهمية تتمية مهارات الكتابة الإقناعية لدى طلاب المرحلة

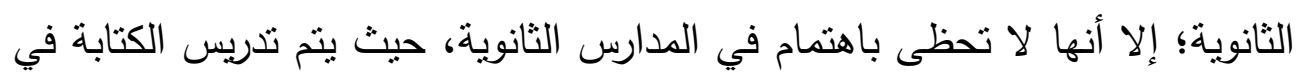
المرحلة الثانوية من خلا موضوعات التعبير التحريري التي نركز على الأحداث الجارية، وكتابة اليوميات، والقصص، ولا تهنم بكتابة الموضوعات الجدلية التي يقدم

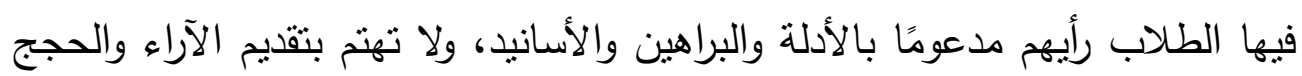

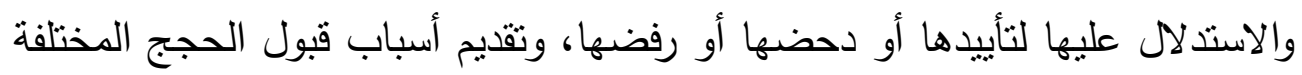

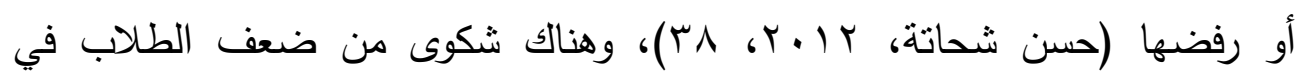
مهارات الكتابة الإقناعية؛ فالطلاب يعانون من صعوبة في تحديد القضية الجدلية التي تلائم الجمهور، وتحديد آرائهم في القضية من خلال المقدمة، وعرض الأدلة المدعومة لآرائهم من خلال منت النص بتسلسل منطقي، وعجزهم عن نوظيف الاقتباسات

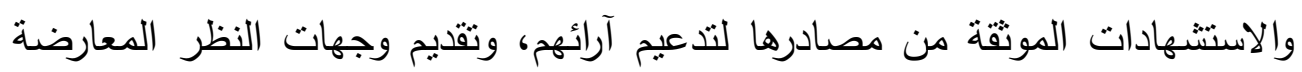

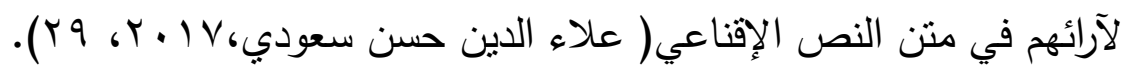
كما يفتقر طلاب المرحلة الثانوية إلى مهارات الكتابة الإقناعية اللازمة لهم؛ حتى يكونوا على مستوى المتطلبات الأكاديمية والمجتمعية، حيث يجدون صعوبة في اختيار الأساليب والتراكيب اللغوية، وعرض الأفكار في تسلسل منطقي يؤدي إلى لى إقناع القراء بآرائهم، كما يعجز الطلاب عن إيجاد العلاقات المنطقية بين الادعاءات

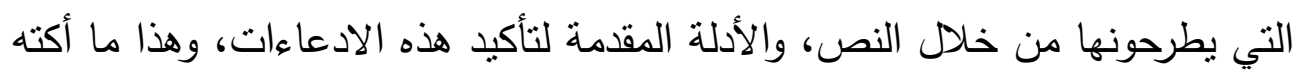

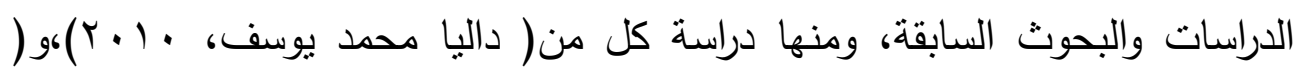

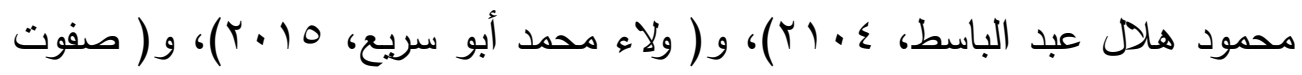

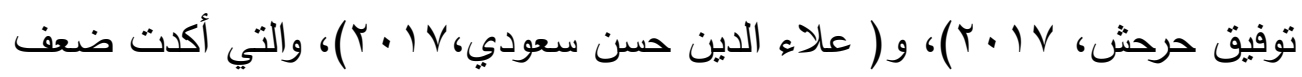

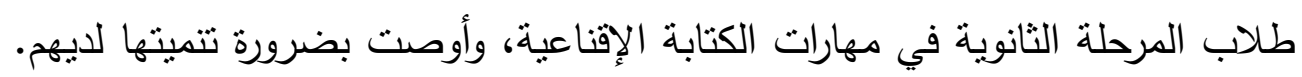


وبالإضافة إلى ما سبق؛ فإن ضعف مستويات أداء الطلاب في مهارات الكتابة الإقناعية قد يرجع ذلك إلى ضعف وعي معلميهم باستخدام طرائق التّريس الملائمة

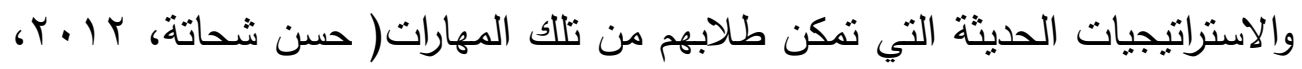
(§)؛ فالكثير من المعلمين لا يتيحون الفرصة لطلابهم لاختيار ما يريدون التعبير عنه من موضوعات وقضايا تهههم، ويميلون للكتابة والتعبير عنها بحرية تامة، كما أن بعض المعلمين لا يهتمون بتدريب طلابهم على مهارات الكتابة الإقناعية بأساليب

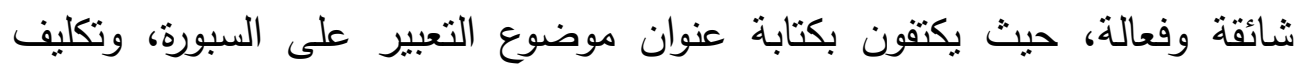
الطلاب كتابته في المنزل، وهذا ما أكدته دراسة (محمود جلال الدين سليمان،9 ـ . ب) التي أثنارت إلى أن ضعف مستويات الأداء الكتابي في المرحلة الثانوية بأتي في مقدمة أسبابه المعالجات التدريسية، التي تهمل التدريب المهاري. وأجرى البحث دراسة استطلاعية على عشرين طالبًا من طلاب مدرسة جمال

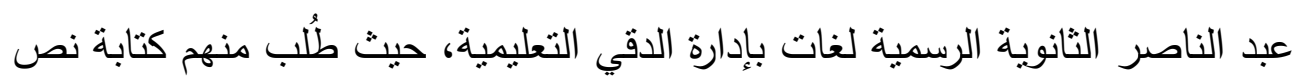
إقناعي حول قضية من القضايا الجدلية في صورة مقال؛ وقد أكدت الدراسة الاستطلاعية أن:

- - 9 من الطلاب لا بستطيعون تحديد القضية الجدلية التي نلائم الجمهور . - - 90 \% من الطلاب لا يستطيعون بناء الادعاءات حول القضية الجدلية. - - - 9 \% من الطلاب لا يستطيعون تحديد البيانات المتصلة بالقضية الجدلية المطروحة. - - - من الطلاب لا يستطيعون تحديد المبررات لإثبات وجهة نظرهم في القضية. - 90\% من الطلاب لا يستطيعون عرض الأدلة التي تدعم آراءهم حول القضية في منن النص بتسلسل منطقي. - . . 1\% من الطلاب لا يستطيعون تفنيد ادعاءات الطرف الآخر حول

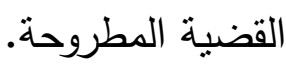


وانطلافًا مما سبق من أهمية تتمية مهارات الكتابة الإقناعية لاى طلاب المرحلة الثانوية، وانطالفًا من ضعف مستوى الطلاب في مهاراتها كما أثارت الدراسات والبحوث السابقة، وما أكدته الدراسة الاستطلاعية، بالإضافة إلى حاجة معلمي اللغة

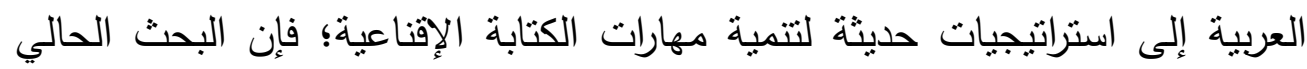
يهدف إلى بناء استراتيجية قائمة على نموذج نولمن في الحجاج لتتمية مهارات الكتابة الإقناعية، وإثارة الدافعية لتعلمها لدى طلاب المرحلة الثانوية. ثالثًا: تحدبد مشكلة البحث:

تتحدد مشكلة البحث الحالي في ضعف مهارات الكتابة الإقناعية لاى طلاب المرحلة الثانوية، وقصور دافعيتهم نحو تعلمها، وللتصدي لهذه المشكلة يحاول البحث الإجابة عن السؤال الرئيسي التالي:

كيف يمكن بناء استراتيجية قائمة على نموذج تولمن في الحجاج لتنمية مهارات الكتابة الإقناعية وإثارة الدافعية لتعلمها لدى طلاب المرحلة الثانوية؟ ويتقرع عن هذا السؤال الرئيسي الأسئلة التالية:

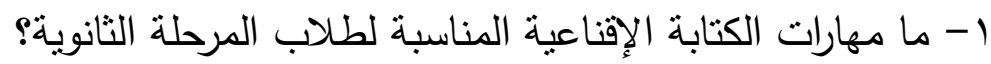

r- ما مؤشرات الدافعية نحو تعلم الكتابة الإقناعية لدى طلاب المرحلة الثانوية؟ الإبه

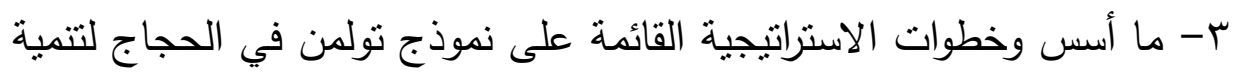

مهارات الكتابة الإقناعية وإثارة الدافعية لتعلمها لدى طلاب المرحلة الثانوية؟ لهوبه ع - ما فاعلية الاستراتيجية القائمة على نموذج نولمن في الحجاج لتتمية مهارات الكتابة الإقناعية لدى طلاب المرحلة الثانوية ؟ الاسنرائه 0- ما فاعلية الاستراتيجية القائمة على نموذج تولمن في في إثارة الدافعية لتعلم

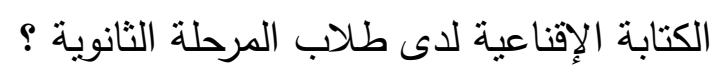
צ- ما مستوى العلاقة بين درجات طلاب المجموعة التجريبية في مهارات الكتابة الإقناعية والدافعية لتعلمها في التطبيق البعدي؟

رابعًا: حدود البحث: اقتصر البحث الحالي على: 
1- طلاب الصف الأول الثانوي؛ وذلك لأن الطلاب في هذا الصف لديهم المرونة العقلية في التفكير التي تمكنهم من استخدام طرق وآليات محددة وواضحة، واستخدام أساليب مقنعة في الكتابة يسوقون من خلالها الحجج؛ ومحاولة الفهم، والقدرة على إجراء المقارنات، لإقناع الآخرين بوجهات النظر

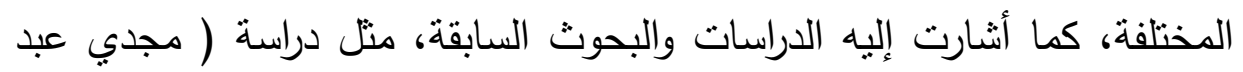

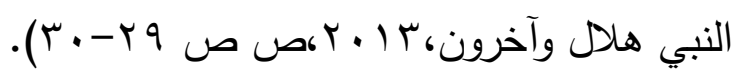

r- مهارات الكتابة الإقناعية المناسبة لطلاب الصف الأول الثانوي، في ضوء ما ما كثفت عنه آراء الخبراء والمتخصصين على القائمة المعدة بالبحث، وذللك الإه استتناجًا من البحوث الدراسات السابقة والتي أكدت أهميتها لهذه المرحلة.

\section{خامسًا: تحديد مصطلحات البحث:}

يُعرف نموذج تولمن في الحجاج بأنه:" مجموعة من المراحل والخطوات المتتابعة تمكن الطلاب من الانخراط في الحجج، تستند إلى ستة عناصر هي: الإدعاء، والبيانات، والمبررات، ومحددات الجهة، وأدلة التفنيد، والدعم ( سلوى الهي

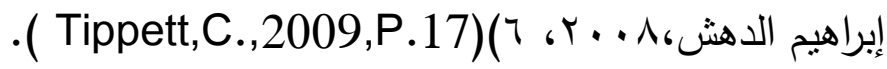
ويعرف النموذج إجرائيًا في البحث الحالي بأنه: مجموعة من الإجراءات يتم الاستتاد إليها لبناء استراتيجية قائمة على نموذج تولمن في الحجاج لتتمية مهارات الكتابة الإقناعية وإثارة الدافعية لتعلمها لدى طلاب المرحلة الثانوية، ويستتد البحث الحالي إلى المراحل والإجراءات والخطوات التي حددها تولمن وفق نموذجه في الحجاج لتتمية مهارات الكتابة الإقناعية لاى الطلاب، وهي العناصر الثلاثة الأساسية اللازمة لبناء الحجة ألا وهي: الادعاء، والبيانات، والمبررات.

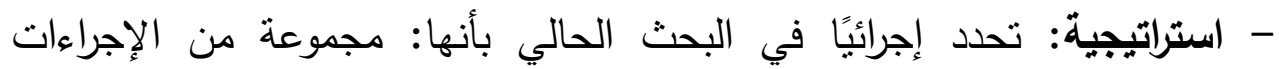
والخطوات المتتابعة التي يقوم بها المعلم؛ لتمكين الطلاب من الانخراط في الحجج كتابة، وتتنمل هذه الاستراتيجية أربع مراحل منتابعة تبدأ بمرحلة التمهيد( التخطيط لكتابة نص إقناعي)، ثم مرحلة كتابة الادعاءات والحجج المضادة، ثم مرحلة المناقنة هرهة التأملية، وتتنهي بالمرحلة الرابعة، وهي مرحلة إنتاج نص الإقناعي. 
- الكتابة الإقتاعية: تحدد إجرائيًا في البحث الحالي: بأن يكتب الطالب نصًا حول قضية معينة، يعبر فيه الطالب كتابة من خلال طرح ادعاء معين مع تقديم الحجج

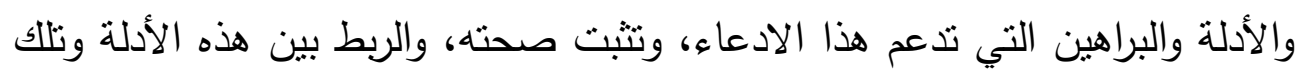
الادعاءات بالمبررات، ودحض الادعاءات المضادة، ثم التوصل إلى إثبات صحة ادعائه، الذي يختم به النص الإقناعي ، وكل ذلك يتم في سياق محدد وفق ترتيب عناصر البنية التنظيمية للنص الإقناعي؛ بغية إقناع القارئ والتأثير عليه.

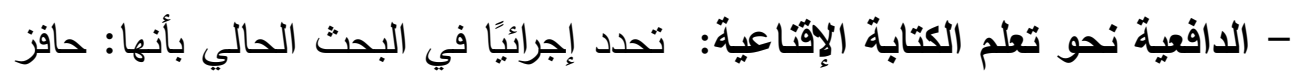
داخلي لدى طلاب الصف الأول الثانوي ينشأ من خلال الاستراتيجية التي يقدمها

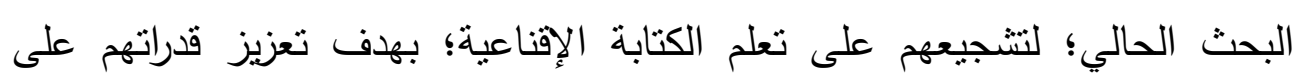
التواصل الاجتماعي، والمشاركة في منافثنة القضايا المعاصرة. سادسًا: خطوات البحث وإجراء|ته:

\section{سار البحث في الخطوات والإجراءات التالية:}

1 - تحديد مهارات الكتابة الإقناعية المناسبة لطلاب الصف الأول الثانوي، وذلك من

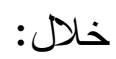

$$
\text { أ- الكتابات التي تتاولت الكتابة الإقناعية . }
$$

ب- الكتابات التي تتاولت طبيعة الطلاب بالمرحلة الثانوية.

$$
\text { ج- آراء الخبراء والمتخصصين. }
$$

ץ- تحديد مؤشرات الدافعية نحو تعلم الكتابة الإقناعية لطلاب الصف الأول الثانوي،

وذلك من خلال:

أ- الكتابات التي تتاولت الدافعية نحو التعلم.

ب-الكتابات التي تتاولت طبيعة الطلاب بالمرحلة الثانوية.

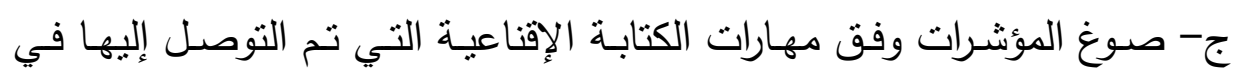
الخطوة السابقة. ج- آرء الخبراء والمتخصصين. 
r- تحديد أسس وخطوات استراتيجية قائمسة على نموذج تولمن في الحجاج لتتميـة مهارات الكتابة الإقناعية وإثارة الدافعية لتعلمها لدى طلاب المرحلة الثانوية ؛ وتم ذلك

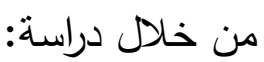

$$
\text { أ- نموذج تولمن في الحجاج. }
$$

ب- مهارات الكتابة الإقناعية التي تم التوصل إليها في الخطوة السابقة. ج- الدافعية نحو الكتابة الإقناعية. د- آراء الخبراء والمتخصصين. ع - بناء الاستراتيجية القائمسة على نموذج تولمن في الحجاج لتتميـة مهارات الكتابة الإقناعية وإثارة الدافعية لتعلمها لدى طلاب المرحلة الثانوية ، وقد تضمنت:

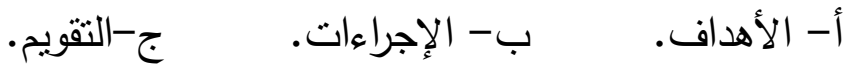

$$
\begin{aligned}
& \text { 0- تطبيق الاستراتيجية، ويتطلب: }
\end{aligned}
$$

أ- اختيار عينة البحث من طلاب الصف الأول الثانوي ، حيث يقوم البحث الحسالي على التصـميم التجريبـي ذي المجموعـة الواحـدة ( المجموعـة التجريبية)؛ لمناسبة ذلك طبيعة البحث الحالي • ب- بناء اختبار الكتابة الإقناعية، وضبطه. ج- بناء مقياس الدافعية لتعلم الكتابة الإقناعية، وضبطه. د- تطبيق اختبار الكتابة الإقناعية على مجموعة البحث قبليًا. هـ - تطبيق مقياس الدافعية لتعلم الكتابة الإقناعية على مجموعة البحث قبليًا. و - تطبيق الاستراتيجية على مجموعة البحث. ز - تطبيق اختبار الكتابة الإقناعية على مجموعة البحث بعديًا. ط- تطبيق مقياس الدافعية لتعلم الكتابة الإقناعية على مجموعة البحث بعديًا. ق - استخراج النتائج، وتحليلها، وتفسيرها. سابعًا:أهمبة البحث: قد يفيد البحث الحالي كلًا من: 
1- مصممي المناهج ومطوريها: حيث يقدم البحث استراتيجية قائمة على نموذج تولمن في الحجاج يمكن الاعتمـاد عليها في تطوير منهج اللغـة العربية في الصف الأول الثانوي.

r- المعلمين: حيث يقدم البحث دليلً يساعدهم في تتمية مهارات الكتابة الإقناعية لاى طلاب الصف الأول الثانوي. r- الطلاب:حيث يساعد البحث في تتمية مهارات الكتابة الإقناعية وإثارة الدافعية لتعلمها لدى هؤلاء الطلاب. ع - الباحثين: حيث يفتح البحث المجال أمامهم لإجراء بحوث أخرى حول نموذج تولمن في الحجاج والكتابة الإقناعية. الإطار النظري

\section{(نموذج تولمن في الحجاج والكتابة الإقناعية والدافعية لتعلمها):}

يهدف العرض التالي إلى: تحديد مهارات الكتابة الإقناعية لطلاب الصف الأول الثانوي، وتحديد مؤشرات إثارة الدافعية لدى هؤلاء الطلاب، وتحديد أسس بناء استراتيجية قائمة على نموذج تولمن في الحجاج لتنمية مهارات الكتابة الإقناعية لدى لهون

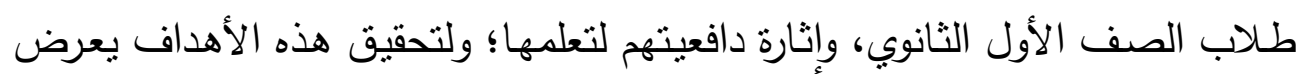
البحث لكل من: الكتابة الإقناعية، والدافعية لتعلمها، ونموذج تولمن في الحجاج على الترتيب كما يلي: أولًا: تحدبِ مهارات الكتابة الإقناعبة لطلاب الصف الأول الثانوي: لتحديد مهارات الكتابـة الإقناعية لطـلاب الصف الأول الثانوي، تجدر الإشـارة إلى استعراض مفهوم الكتابة الإقناعية، وأهميتها، ومهاراتها، وعناصر كتابة النص الإعاعله الإقناعي، وتتمية مهاراتها لاى طلاب المرحلة الثانوية. 1 - مفهوم الكتابة الإقناعية:

تعددت الآاري التي تتاولت مفهوم الكتابة الإقناعية، حيث يعرفها كل من نيبولا ولونرجان وفانيينج (Nippold, M., Lonergan, J. \& Fanning, J. 2005) 
بأنها:" نوع من أنواع الكتابة الجدلية التي تستخدم المنطق والسبب لتعطي الأفضلية

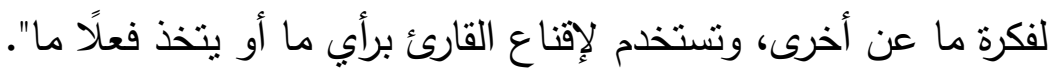

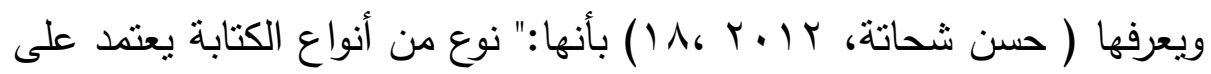

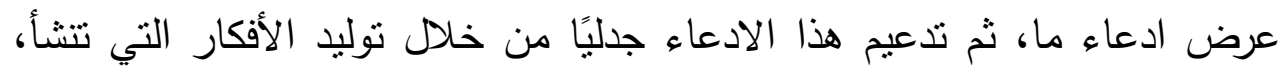
ومن خلال خبرات سابقة لدى الفرد تساعده على تحليل أنواع الموقف الذي يتعرض هن له؛ بهدف إقناع القارئ بقبول وجهة نظر الكاتب، وعرض الآاره المضادة ودحضها

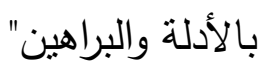

كما يرى وينجات (Wingate,U.,2012,p.146) أن الكتابة الإقناعية " شكل اجتماعي يعرض فيه الكاتب الموقف الذي سيدافع عنه من خلال عرض سلسلة من الادعاءات المترابطة والبيانات والأسباب المتصلة بها، مع الترتيب المنطقي للافتراضات أو الاقتراحات التي تنبي الموقف".

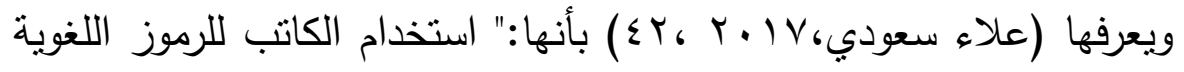

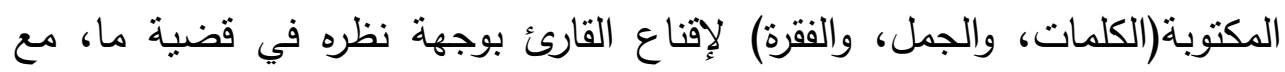
تقديم الأدلة التي تؤكد رأيه، وتقند الآراء المعارضة لهه". ويرى البحث الحالي أن الكتابة الإقناعية: كتابة الطالب نصًا حول قضية معينة، يعبر فيه كتابة من خلال طرح ادعاء معين، مع تقديم الحجج والأدلة والبراهين التي تدعم

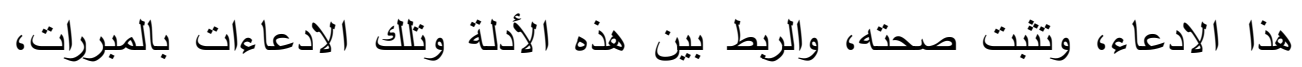
ودحض الادعاءات المضادة، ثم التوصل إلى إثبات صحة ادعائه، الذي يختم به النص الإقناعي ، وكل ذللك يتم في سياق محدد وفق ترتيب عناصر البنية التنظيمية للنص الإقناعي؛ بغية إقناع القارئ والتأثير عليه.

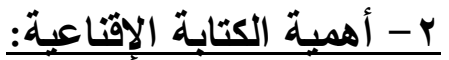

يري كل من (Nippold, M., Lonergan, J. \& Fanning, J. 2005) و (Y)

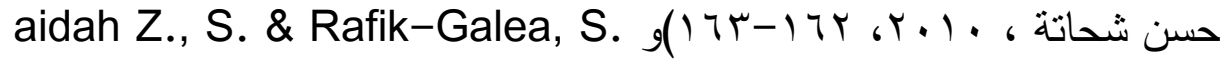
(Beyreli, L. \& Konuk, S. 2018) (2016.p.133) الإقناعية دورًا مهمًا في: المدرا 
- - بناء شخصية الطلاب، وتأهيلهم ليكونوا أعضاء فاعلين في المجتمع.

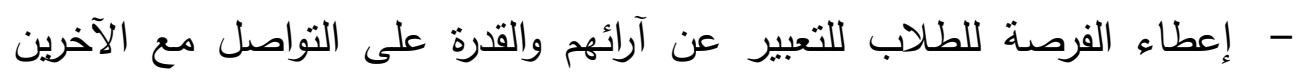
بحرية ومسئولية..

- مساعدة الطلاب على تقديم الأدلة التي تؤيد موقفًا معينًا أو ادعاءً معينًا. - تعزيز دور الطلاب في المشاركة الإيجابية في قضايا مجتمعه، ومشكلاته. - الدفاع عن قضاياهم ووجهة نظرهم بصورة منطقية. - مساعد الطلاب على تحليل القضايا، ومناقتشها، وحل المشكلات بطريقة منطقية. - ت تمية قدراتهم على توليد الحجج والأدلة المقنعة. - - تحسين المستوى الأكاديمي والتحصيل الدراسي لدى الطلاب. - تتمية مهارات التفكير الناقد لاى الطلاب، والتي تعد من بين المهارات الأساسية التي يحتاجون إلى تعلمها للحياة في القرن الحادي والعشرين. - - الخروج بالتفكير في العالم الصغير داخل المدرسة؛ إلى التفكير في العالم الكبير خارجها. - - نمو الدافعية لدى الطلاب نحو الكتابة، حيث يتحولون إلى كتاب فاعلين وإيجابيين.

\section{r- مهارات الكتابة الإقناعية:}

تتطلب الكتابة الإقناعية امتلاك الطالب مجموعة من المهارات التي تساعده عند كتابة نص إقناعي؛ ولهذا سعى الباحثون إلى تحديدها وتصنيفها، حيث حدد كل من كوهل وأدل (Kohn.,D., \& Udell,W.,2003,PP.1245-1248) مهارات الكتابة الإقناعية في: توليد الادعاءات، وتدعيم الادعاءات بالحجج والبراهين، وعرض الادعاءات المضادة، وتفنيد الادعاءات المضادة، ويكاد يتفق مع هذا التصنيف ما حده (Udell\&W., 2007,PP.341-342) الذي أوضح أن مهارات الكتابة الإقناعية تتمثل في: عرض الادعاء الرئيسي، وتحديد القضايا المرتبطة بالادعاء

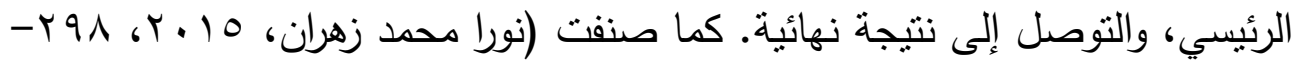
999) مهارات الكتابة الإقناعية إلى مهارات مرتبطة بالجانب الفكري الإقناعي، 
ومهارات مرتبطة بالجانب التتظيمي، ومهارات مرتبطة بالجانب الأسلوبي. وقد

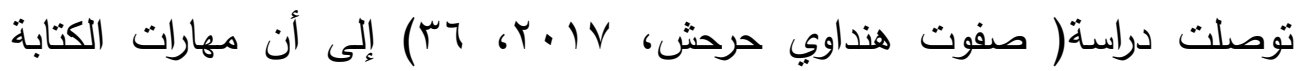
الإقناعية تتمنل في: عرض ادعاء ما أو قضية، وتدعيم الادعاء بالأدلة، وعرض دران الآارع المضادة، وتقنيد الادعاءات المضادة، والتوصل إلى نص إقناعي صحيح. ووفق ما سبق، فإن الكتابة الإقناعية تحتاج إلى وضوح الفكرة، والانتقال من فكرة إلى إلى فكرة أخرى بطريقة واضحة ومنطقية، واختيار الكلمات والعبارات والجمل المناسبة، ومراعاة العلاقة بينها، وكذللك مراعاة قواعد البناء اللغوي الصحيح، كما أنها تحتاج إلى حجاج قوي يقوم على المنطق والاستدلال، ويقبله العقل؛ حتى يصل إلى الإقناع، وتتطلب التتظبم الجيد؛ بما يجعلها تتميز عن غيرها من أنواع الكتابة بينية تركيبية محكمة تتتاسب مع الأسلول الإقناعي المتبع. وقد أمكن للباحث من خلال العرض السابق تحديد بعض مهارات الكتابة الإقناعية التي يمكن تتميتها لدى طلاب الصف الأول الثانوي، وهي: - - اختيار نوع القضية المناسبة لطبيعة الجمهور المستهدف. - - كتابة مقدمة تعبر عن وجهة نظره تجاه القضية المطروحة. - تقسيم النص الإقناعي إلى مقدمة ومتن وخاتمة. - - تحديد الادعاء الرئيسي( رأيه) حول القضية المطروحة. - مرح بيانات ومعلومات صحيحة حول القضية المطروحة. - - عرض الحجج والأدلة المدعمة لرأيه بنسلسل منطقي. - كتابة المبررات التي ترتبط بالبيانات وتدعم رأيه حول القضية. - - تقديم وجهات النظر المعارضة لرأيه بدقة. - تقنيد الآرء المضادة لرأيه بدقة ودحضها بوضوح ل

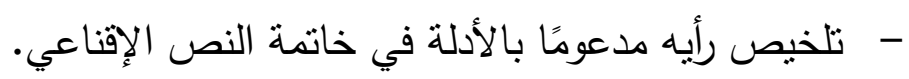
ع- عناصر النص الإقناعي:

Nystrand, M. \& Graff, N.,2001,p.82) حدد كل من نيستراند وجراف ) عناصر البنية التنظيمية للنص الإقناعي، والتي تتمنل في : 
- الادعاء أو الأطروحة التي تختلف حولها وجهات النظر - البرهان أو الدليل الذي بدعم هذا الادعاء. - - الأسباب أو المبررات المنطقية التي توضح العلاقة بين الادعاء والبرهان، وتربط بينهما. - الادعاءات المضادة، أو وجهات النظر المعارضة للادعاء المطروح. - - تفنيد الادعاءات المعارضة.

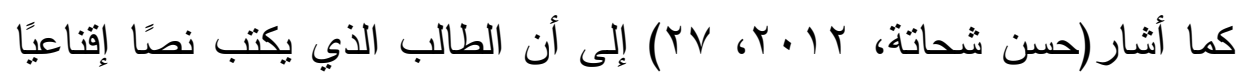
صحيحًا؛ فهو في حاجة إلى مجموعة من العناصر التي ترتبط بطبيعة النص إس إس الإقناعي، وهي:

- - الفكرة الرئيسية التي يود إثباتها أو تأكيدها. - - الحقائق أو الأدلة أو المبادئ التي تدعم الادعاء أو الرأي. - العبارات التي تربط الأدلة بالدعاء بما بدعم الادعاء.

(Farous I., A. \& Ummul, A. , كما يرى كل من فاروس ويومال 2017,pp.287) - البدء بجملة افتتاحية تخبر القارئ عن الفكرة الأساسية للنص. - - موضع الأسباب والحجج التي تدعم الفكرة.

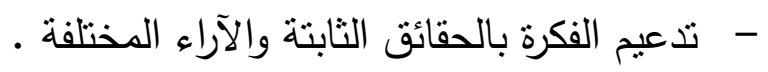
- استخدام الحوار أو القصة أو عرض الصور أوراء الأشكال داخل النص الإقناعي؛ من أجل إقناع القارئ.

ومن ثم يجدر بالمعلم عند تدريب الطلاب على كتابة النص الإقناعي مراعاة خطوات الكتابة الإقناعية، وهي: عرض الادعاء، والدليل الذي يدعم هذا الادعاء، والأسباب (المبررات) المنطقية التي توضح العلاقة بين الادعاء والدليل، ثم عرض الإديه الادعاءات المضادة، وتفنيدها. ه- تثمية مهارات الكتابة الإقتاعية: 
Abdul Aziz,F.,\& ) يثير كل من عبد العزيز وأحمد (Ahmad,U.,2017,pp.9-10 إلى أن نموذج تولمن في الحجاج يعد من بين أفضل النماذج التي تقدم خطوات متتابعة ومحددة، يمكن أن تناعد الطلاب على بناء ادعاءاتهم حول القضية المطروحة؛ فيتعلمون كيف يستخدمون أفكارهم، ويكتبونها بتسلسل منطقي؛ من أجل إقناع الآخرين بوجهة نظرهم. وفي السياق ذاته يذكر وود (Wood, N.. 2001) أن نموذج تولمن في الحجاج يدعم الطلاب في كتاباتهم الإقناعية، حيث يقدم أرضية ثابتة، وجسرًا مشتركًا كل من وند

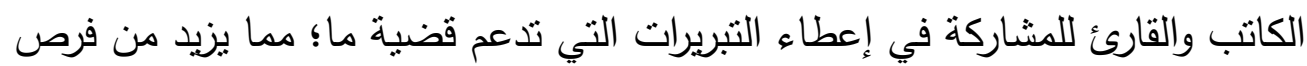
التفاعل بينهما، ويشجع تبادل الآراء. كما يشير سيلر(Seyler, D., 2002 ) أن استخدام نموذج تولمن في الحجاج يشجع الطلاب على التفكير بطريقة منظمة ومنطقية، ويساعدهم في حل المشكلات التي قد تواجهم بطريقة صحيحة، ويؤكد جونسون وآخرون ( Johnson,T.et al.,,2012,p.136) أن استخدام نموذج نولمن في الحجاج يعطي الفرصة للطلاب لبناء الأدلة، وكتابة المبررات التي تدعم ادعاءاتهم حول القضية المطروحة.

ويذكر والتون وآخرون(Walton,et al.,2008)أن نموذج تولمن في الحجاج لا يعتمد على المنطق فحسب، ولكنه يعطي أدلة قوية؛ لأنه يمنح الفرصة للقارئ لتفنيد

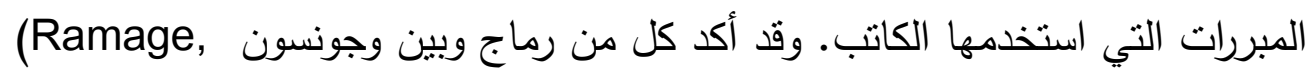
أن الادعاء الجيد يجب أن يرتكز على ثلاثة عناصر أساسية هي : الرسالة والكاتب والقارئ، وهذه العناصر الثاثنة متداخلة تعد الأساس في عملية الإقناع عند كتابة النص الإقناعي.

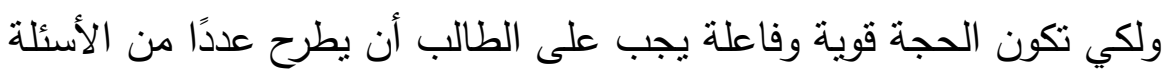
الذاتية عند كتابة النص الإقناعي(55-48.prish, R. K.2003,pp.):

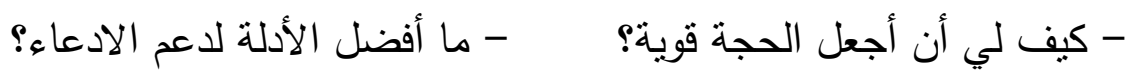
- - كيف لي أن أجد أفضل التعليلات التي تدعم الفكرة مع أفضل الأدلة؟ - - كيف أستطيع أن أجعل القارئ ينتبه إلى رسالتي؟ 
- كيف لي أن أضع تعليلي ليثق بي القارئ، وأجعله عند حسن ظني؟

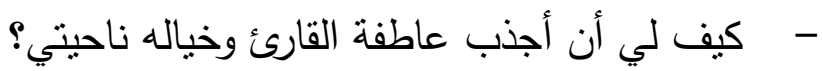

- - كيف لي أن أعبر عن نفسي بفاعلية؟ إن الإجابة عن الأسئلة السابقة سوف تؤدي إلى بناء اعنى حجة واضحة قوية ومنطقية، وبالإضافة إلى ذلك، فإنه عندما بريد الكاتب أن يثبت حجته؛ فإن عليه تقديم عدد من الأدلة القوية التي تدعم حجته ؛ فعلى الطالب الذي يكتب نصًا إقناعيًا أن يسأل نفسه: هل تعد الأدلة التي قدمتها كافية لاعم حجتي؟ ومن ثم، وفي ضوء ما سبق، أمكن التوصل إلى مجموعة من الإجراعات

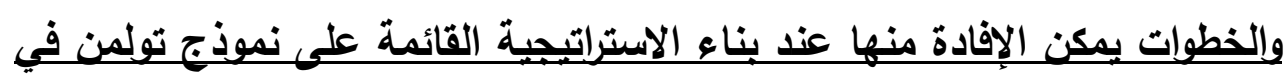
الحجاج لتنمية مهارات الكتابة الإقناعية لاعى الطلاب: - - تقديم مواقف تتضمن موضوعًا جداليًا أو حدثًا متتاقضًا. - تزويد الطلاب بالبيانات المرتبطة بموضوع الججاج واللازمة لبناء ادعاءاتهم، أو موال توجيه8م للبحث عنها. - توفير مصادر للحصول على بيانات وأدلة. - تزويد الطلاب بنموذج إرشادي لبناء الحجة تتضمن عناصرها. - تكوين مجموعات عمل للمناقثة وبناء الحجج المبدئية. - - إتاحة الفرصة للمناقتشة بين المجموعات لتفنيد ادعاءات بعضهم البعض.

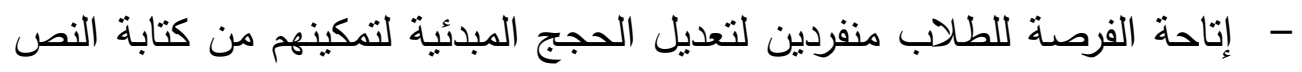

$$
\text { الإقناعي. }
$$

- - إتاحة الفرصة للطلاب لإجراء المناقثات الحجاجية المكتوبة بأنفسهم. - تقديم التغذية الراجعة من قبل المعلم للحجج التي استتدوا إليها. ثانيًا: تحدب مؤشرات إثارة الدافعية لتعلم الكتابة الإقناعية لدى طلاب الصف الأول الثُانوي:

لتحديد مؤشرات إثارة الدافعية لتعلم الكتابة الإقناعية لاى طلاب الصف الأول الثانوي؛ تجدر الإثارة إلى استعراض مفهوم الدافعية للتعلم، وطرق إثارة الدافعية نحو 
التعلم، وذلك للوصول إلى المؤشرات المرتبطة بإثارة الدافعية لتعلم الكتابة الإقناعية لدى هؤلاء الطلاب. 1- مفهوم الدافعية للتعلم: تعرف الدافعية للتعلم بأنها:" حالة داخلية توجه سلوك

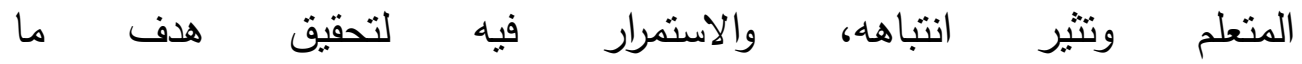
(Guay et al.,2010,p.712)(Broussard\&Garrision,2004,p.106)

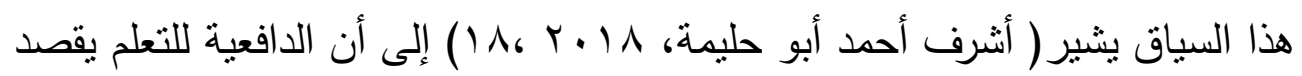

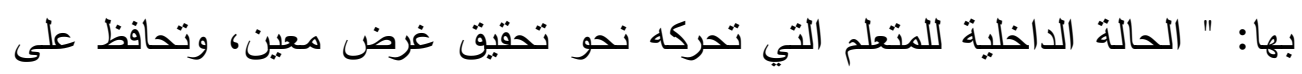
استمراريته؛ حتى يتحقق ذلك الهدف". ومن هنا يمكن استخلاص أن الدافعية للتعلم هي تكوين داخلي يعبر عن الحالة

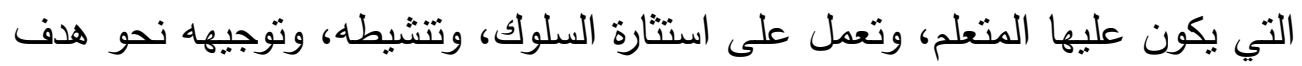
معين، ويمكن أن بستدل على هذه الحالة من تتابعات السلوك الموجهة نحو الهدف، وتتتهي هذه التتابعات بتحقيق الهدف موضوع الدافع، وأنها تتكون من ثلاثة جوانب هي: الجانب المعرفي، والجانب الوجداني، والجانب السلوكي. ومما سبق بمكن تعريف الدافعية لتعلم الكتابة الإقناعية بأنها: حافز داخلي لدى لي طلاب الصف الأول الثانوي ينشأ من خلال الاستراتيجية التي يقدمها البحث الحالي؛ لتشجيعهم على تعلم الكتابة الإقناعية؛ بهدف تعزيز قدراتهم على التواصل الاجتماعي، والمشاركة في مناقثنة القضايا المعاصرة.

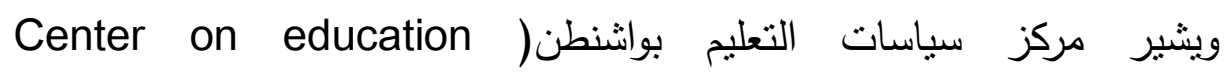
(polcy,2012 إلى أن الدافعية للتعلم تتكون من عدة أبعاد هي: - الكفاءة: وتعني قدرة الطلاب على إكمال المهام الموكلة إليهم.

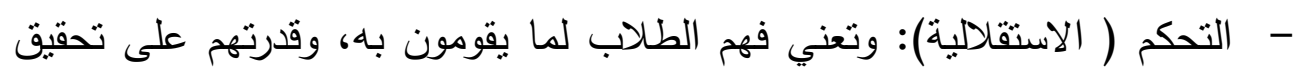

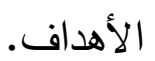

- الاهتمامات: وتعني إقبال الطلاب على تتفيذ الأنشطة وأداء المهام بصورة أفضل. - - القيام بالواجبات من أجل تحقيق الأهداف. 
ويشير مارتن(Martin,2106) إلى أن الدافعية للتعلم تساعد الطلاب على

اكتساب المهارات اللغوية بصورة أفضل. ץ- طرق إثارة الاففية للتعلم: هناك طرق متعددة يمكن استخدامها لإثارة الدافعية

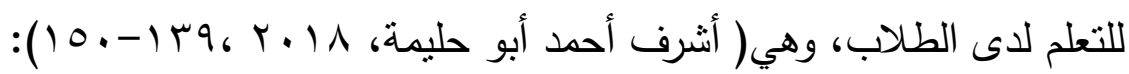

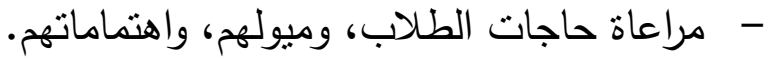
- - مراعاة الفروق الفردية بين الطلاب. - - استثمار الخصائص العقلية للطلاب وذكاءاتهم المتعددة. - - تهيئة بيئة صفية محفزة للتعلم ومعززة لله. - مشاركة الطلاب في التخطبط للدرس. - - تثجيع التعلم التعاوني والعمل الجماعي بين الطلاب. - تعزيز المشاركة الإيجابية لدى الطلاب. - - تتويع المثيرات باستخدام الوسائط التعليمية المتعددة. - توظيف التكنولوجيا في أثناء عملية التعلم. - تتويع أساليب التدريس في أثناء عملية التعلم. - - تتويع الأنثطة المستخدمة في أثناء التعلم. - ربط موضوع التعلم بحياة الطلاب. - تزويد الطلاب بنتائج أعمالهم فور الانتهاء منها. - - تقديم التغذية الراجعة المستمرة في أثناء التعلم. ووفقًا لما سبق أمكن تحديد مجموعة من المؤشرات المرتبطة بإثارة الدافعية لتعلد الكتابة الإقناعية لدى طلاب الصف الأول الثانوي، في ثلاثة جوانب كالتالي :

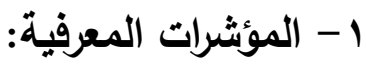

- يقوم بجمع البيانات والمعلومات حول القضايا الخلافية. - يعرض الفكرة حول القضية بصورة صحيحة. - يبدي رأيه في القضايا المختلفة بصورة صحيحة. 
- بدعم أفكاره لإقناع القارئ بها. - يكتب الأدلة بدقة.

- يكتب المبررات الداعمة لفكرته. - يفند وجهات النظر المعارضة - يصل إلى نتائج من خلال المقدمات المعطاة. r - المؤشرات الوجدانية: - - يقبل على الكتابة دون تردد. - - يشارك زملاءه في التخطيط لكتابة نص إقناعي. - ينتل بين خطوات الكتابة الإقناعية بيسر وسهولة. - يتعاون مع زمالئه في أثناء كتابة النص الإقناعي. ب- المؤثرات السلوكية: - يناقش القضايا الجدلية مع زملائه. - يبحث في القضايا الجدلية المعاصرة التي تشغل الرأي العام. - - يستخدم اللغة العربية السليمة للتعبير عن أفكاره وآرائه. - - يحسن من كتاباته باستمرار • وفي ضوء العرض السابق لكل من الكتابة الإقناعية وإثارة الدافعية لتعلمها أمكن استخلاص الأسس التالية لبناء استراتية تستهدف تنمبة مهارات الكتابة الإقّاعية، وإثارة الدافعية لتعلمها لاءى طلاب الصف الأول الثانوي: - تشجيع التعلم التعاوني والعمل في فريق بين الطلاب في أثناء كتابة النصوص الإقناعية.

- - استخدام أساليب تهيئة محفزة معززة للطلاب في أثناء تعلم الكتابة الإقناعية. - تقديم التغذية الراجعة المستمرة؛ لتقوبم كتابات الطلاب، والحكم على جودة النصوص الإقناعية.

- توظيف أساليب العرض العملي المشوقة والمثيرة للانتباه، ومشاركة الطلاب خلال تتفيذها، وتشجيعهم لتأمل خطوات كتابة النص الإقناعي، ومناقشة عناصره. 
- توفير الدعم والتشجيع المنواصل لمساعدة الطلاب على كتابة نصوص إقناعية صحيحة وهادفة.

- إتاحة الفرصة كاملة للطلاب لعرض كتاباتهم، وتعديلها، وفق التغذية الراجعة المستمرة.

- - بث الثقة في نفوس الطلاب، وإعطائهم المسئولية كاملة في أثناء تعلم الكتابة الإقناعية، ودعمهم، وتصويب أخطائهم دون نقد.

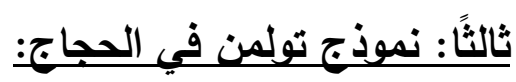

يعد نموذج تولمن في الحجاج واحدًا من أهم النماذج المعاصرة، والتي أثرت

بشكل كبير في دراسات الحجاج المنطقي في النصف الثاني من القرن العشرين؛ حيث

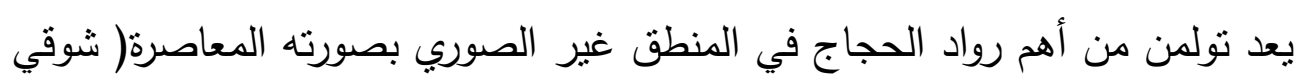

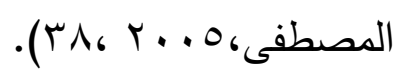

وقد طرح تولمن نموذجه في الحجاج في كتابه استخدامات الحجة عام19019

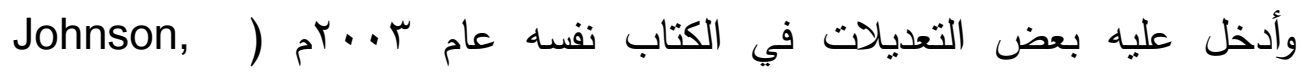
(R.,2005,pp.222-225)، والذي أثنار فيه إلى أن الحجاج يعد أداة مهمة من فئه أدوات التحليل المنطقي، وأنه ذو فاعلية في حل إثكاليات عديدة، وهو أداة طيعة

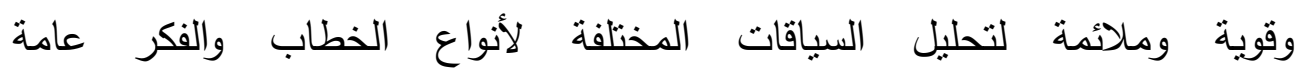
(Toulmin,S, 2003,pp.321) غير الصوري، وهو أحد فروع المنطق المعاصرة ، والذي يعتمد الحجاج والتفكير

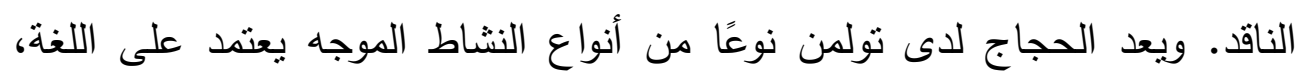

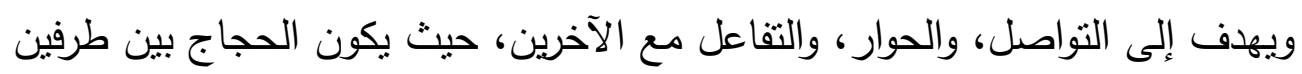

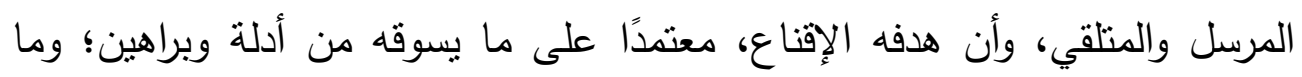

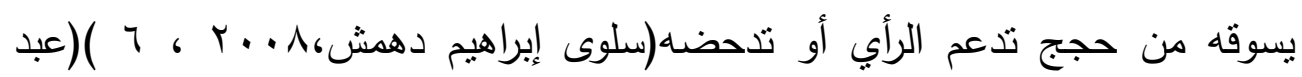

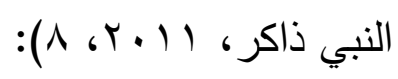
- مراحل نموذج تولمن في الحجاج: 
يستتد النموذج الذي قدمه نولمن في الحجاج إلى مراحل وإجراءات منتابعة تحدد ست وظائف للحجج هي: الادعاء، والبيانات، والمبررات، ومحددات الجهة، وأدلة التفنيد أو دحض حجة الادعاء ، والدعم، وهو عنصر يتعلّق أساسًا بالتبرير

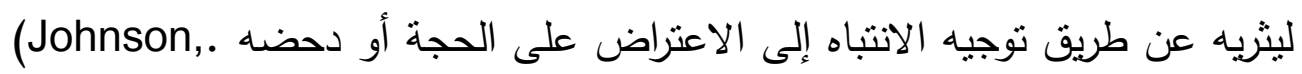

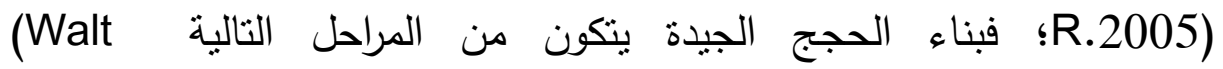
:( Zainuddin ,Z.,\& Rafik-Galea., SH.,2016) D.2008,p.26) - المرحلة الأولى: الادعاء: والادعاء هو الثيء المُطالب بـه أي ما يريد الفرد إثباته،

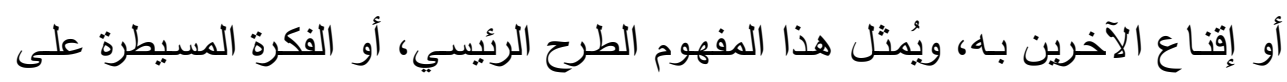
صيغة القضية التي تمثل موضوع الجدل.

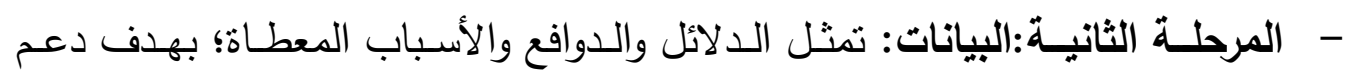
الادعاء أو الفكرة الرئيسية، ومساندتها؛ فالبيانات يستخدمها صاحب الادعاء لإقناع

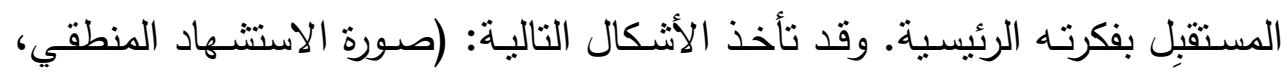

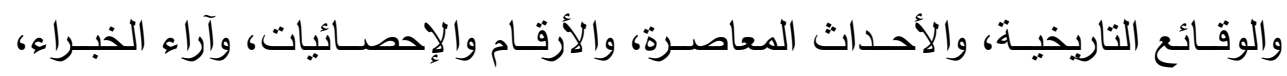

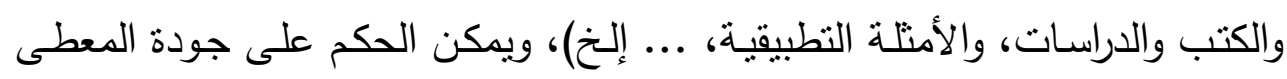
بطرح الأسئلة حول كفايته ومصداقيته ودقته كالتالي: • هل يوجد دليل كافٍ لاعم الادعاء؟ هل يأتي الدليل من مرجع محايد؟ • هل يعد الدليل حقيقيًا؟ المرحلة الثالثة: المبررات: ويعتمد تبرير سلامة الحجة على الأرضية المشتركة بين المرسل والمتلقي،حيث تربط تلك المبررات بين الادعاء وبين معطيات دعمها، وأدلتها، وأسبابها، أو تأييدها. - المرحلة الرابعة: المحددات: وهي العبارات التي تدل على قوة الحجج، والثروط التي تكون فيها الحجج صحيحة. - المرحلة الخامسة: أدلة التقنيا: وتعني العبارات التي تصف الظروف التي تكون فيها الحجة غير صحيحة، وتستخدم لاحض الحجة. 
- المرحلة السادسة: الاعم: وهي عبارات ضمنية تعمل على دعم المبررات أو الأسباب الجيدة للحجة، وهو من العوامل التي تتكل مساعدة أو عونًا للحجة؛ كي تكون أكثر

$$
\text { قبولًا ومصداقية لدى الآخرين. }
$$

ووفقًا لما سبق؛ فإن نموذج تولمن في تخطيط الحجج بستند إلى ستة عناصر رئيسية؛ منها ثلاثة عناصر أساسبة، وثثلاثة أخرى ثانوية، وهي كالتالي: - الادعاء، ثم البيانات، وهي الأدلة الداعمة والمؤيدة للادعاء، ثم المبررات التي تبرر علاقة الادعاء بالدليل؛ وهي العناصر الأساسية لنموذج الحجاج عند نولمن، وهي خطوات يجدر بـالمعلم القيام بها لتنميـة مهارات كتابة النص الإقناعي في تسلسل منطقي، بحيث يستطيع الطلاب عن طريق هذه العناصر أن يحددوا القضية التي يتبنوهـا، ويقومـوا بترتيـب أفكارهم بشكل منطقي متسلسـل، وكذلك تحديد مـا يدعم قضيتهم من أدلة وبراهين، بالإضافة إلى وضع حجج تبرر ونوضتح العلاقة المنطقية أو السبب الذي يربط الدليل بالادعاء، لكي ثُؤمن لهم إثبات ادعائهم وتبرر حجتهم

\section{الرئيسية.}

- أما عناصر النموذج الثانوية، وهي: محدات الجهة، وشروط الاعتراض أو الطعن على الادعـاء، وحجـج الـدعم، يسـنطيع الطـلاب مـن خلالهـا أن يـافعوا عن حججهم فيمـا يواجههم من انتقادات؛ ممـا يعزز ثقتهم بحججهم، ويؤصل رغبتهم في الفوز بصـة ادعائهم، كمـا يكتسبون فن التحاور والجدل وتقبل الحجـج والآراء المعارضـة لحججهم، وكذلك فن مقارعة الحجة بالحجة، وبناء نسق حجاجي سليم. وفي ضوع ما سيق بمكن تقديم بعض الاستنتاجات المرتبطة بنموذج تولمن في

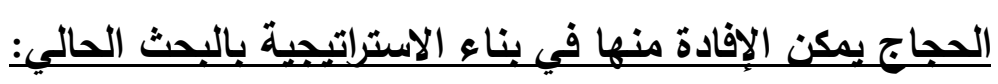
- الحجاج مجموعة من الممارسات التي تتم داخل الفصل من خلال أنشطة أو مهام محددة توجه الطلاب إلى صوغ الادعاءات، والدفاع عنها بالأدلة، وتوجيه تساؤلات حول ادعاءات الآخرين، وتقنيد هذه الادعاءات بالأدلة. - للحجاج منتج هو الحجة، وهو الجزء المنطوق أو المكتوب الذي يوضح الادعاء 
- - من أهم أنواع الحجة: الادعاءات، وأدلة الدعم المناسبة، والاستدلال الذي بربط بين الادعاء والداليل ودحض الحجج المضادة.

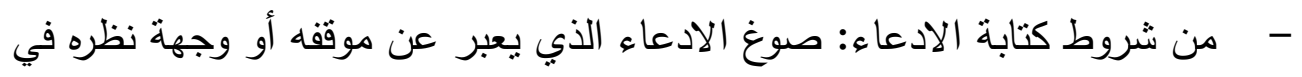
القضية المطروحة بطريقة واضحة ومحددة، وتتفق مع الثقافة العلمية والمجتمعية، مزودًا بليل داعم ومناسب له.

- عند كتابة البيانات؛ فعلى الطلاب استخدام مصادر بيانات صحيحة وموثوق بها، واستخدام البيانات للاففاع عن الادعاء، وتعزيز وجهة نظرهم، وتقديم أمتلة وتبريرات صحيحة للربط بين الأدلة والادعاء.

-

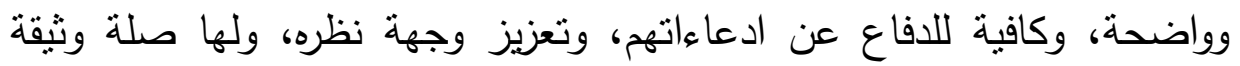
بالقضية المطروحة. - عند كثابة المبررات، على الطلاب دعم وجهة نظرهم بعبارات صحيحة واضحة لها علاقة بموضوع الادعاء. - - عند كتابة الدحض أو التفنيد؛ على الطلاب تفنيد الادعاءات المضادة، وتقديم أدلة ومبررات لاحض الحجج المضادة.

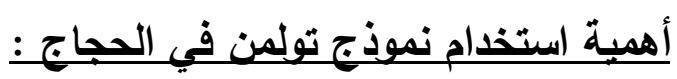

(Driver, R., تكمن أهمية استخدام نموذج ستيفن نولمن في الحجاج فيما لئيلي Voss, F. Newton P., \& Osborne, J., op.cit,2000, p.293) ,Z.,\& (León, J., 2011,pp.130-136) ( J.,2005pp.321-329) :( Zainuddin Rafik-Galea.,SH.,2016) - - ينمي مهارات التفكير الناقد لدى الطلاب.

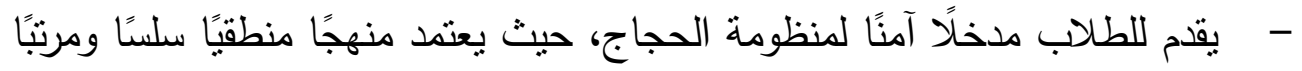

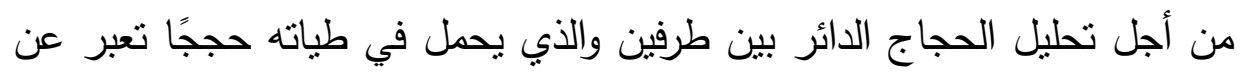
وجهتي نظر مختلفتين في مناظرة حجاجية، سواء كان ذللك عبر مناظرة كلامية خاصة أو عبر نص إقناعي، بحيث يقوم الحجاج في هذه المنظومة بين علدٍ من 
الحجج المؤيدة والمعارضة من أجل إثبات أو دحض قضية ما، وتحكم هذه المنظومة عددًا من المعايير الثابتة والمتغيرة وفقًا لطبيعة كل مجال من المجالات

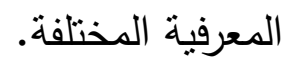
- يستطيع هذا النموذج التعامل مع التباين والاختلاف بين درجات صعوبة القضايا التي يتعامل معها الطلاب، بحيث يتعامل مستخدم النموذج مع قضايا أكثر صعوبة من التي قبلها، ويتمكن من حلها بنفس الطريقة. - يقدم للطلاب إجابات تقصيلية مرنبة موضحًا فيها النقاط الصعبة، وعارضًا لخطوات الحل.

- - يمكن الطلاب من التعامل مع مناظرات الحجاج ومحاوراته بصورة فعالة. - يمكن الطلاب من تفنيد ما يعترضهم في الحياة اليومية من حجج وأفكار وقضايا، سواء على المستوى الثخصي أو على مستوى ساحة الرأي العام.

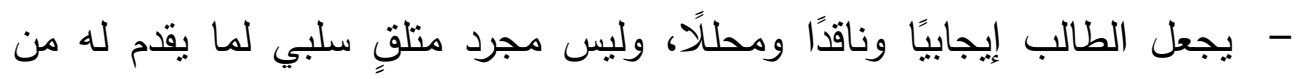
حجج ومعلومات وأفكار . - يمكن الطلاب من مهارات الحوار الفعال ؛ فيستطيعون مقارعة الحجة بالحجة السليمة. - - يمكن الطلاب من تفنيد القضايا المختلفة التي تطرحها وسائل الإعلام المكتوبة أو المرئية أو المسموعة. - يمكن تعليمه وتعلمه بسهولة لمرونته، حيث تكمن مرونته في استيعابه للتطوير

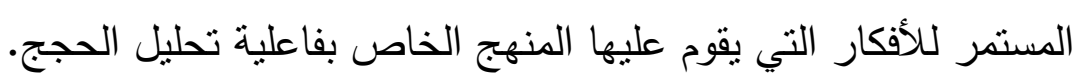
- يوجه الطلاب إلى كيفية التعامل مع الجمهور المتلقي والتحاور معه. - يساعد الطلاب على استكمال كتابة النص الإقناعي بصورة جبدة. - يساعد الطلاب على اكتشاف الأخطاء الثائعة لديهم في كتابة النص الإقناعي. - يعطي الفرصة للطلاب لتقويم كتاباتهم، وتعديلها، وتطويرها وفقًا للنموذج المحدد.

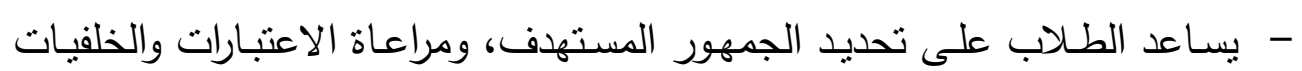
الثقافية له. 
ووفقًا لما سبق فإن نموذج تولمن في الحجاج ذو طابع تعليمى قابل للنطبيق بشكل عملي؛ لأن هدفه الأساسي هو تعزيز الإقناع لدى المتعلمين، آخذًا في الاعتبار قدرات

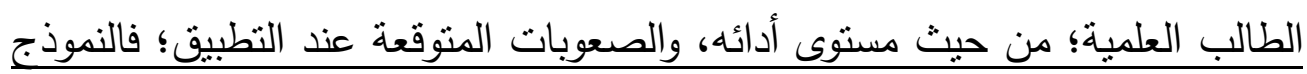
يقدم وسيلة منطقية سهلة ويسيرة للمتعلمين؛ من أجل اكتساب مهارات الخطاب

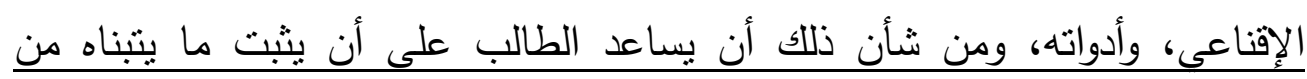
ادعاءات أو حجج ، أو يفند ما يعرض عليه من حجج بطريقة منطقية وعلمية. بناء استراتيجية قائمة على نموذج تولمن في الحجاج لتنمبة مهارات الكتابة الإقناعية وإثارة الدافعية لتعلمها لاع طلاب الصف الأول الثانوي وتطيقها: - يتناول هذا المحور عرضنًا لخطوات بناء استراتيجية قائمسة على نموذج تولمن في

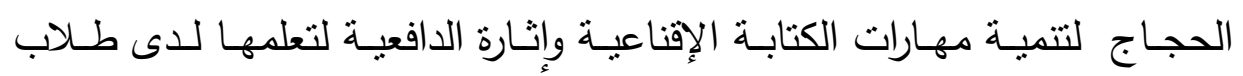
الصف الأول الثانوي ، وقد تضمنت الاستراتيجية كلاً مما يلي:

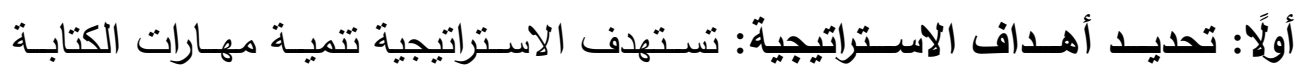
الإقناعية وإثارة الدافعية لتعلمها لدى طلاب الصف الأول الثانوي ؛ وذلك من خلال بنـاء قائمـة مهارات الكتابـة الإقناعيـة المناسبة لطـلاب الصف الأول الثانوي ، وبيان ذلك كما يلي: ا - تحديد الهـف مـن بنـاء قائمـة مهارات الكتابـة الإقناعيـة لطـلاب الصف الأول

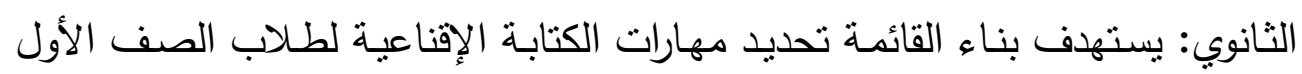
الثانوي ، والتي تستهدف الاستراتيجية تتميتها لدى هؤلاء الطلاب.

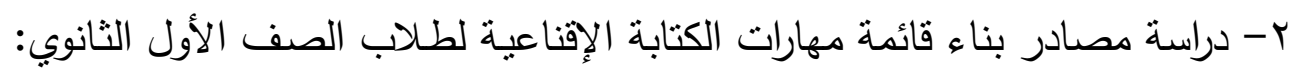

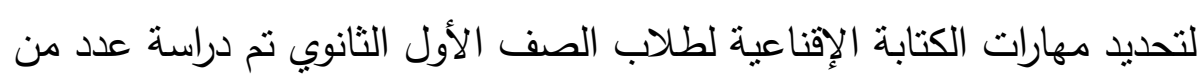
المصادر منها على سبيل المثال:

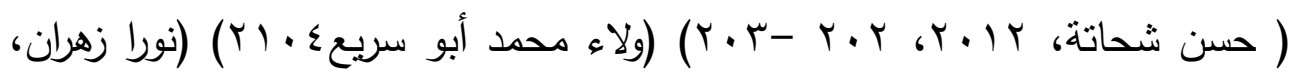
10) 10

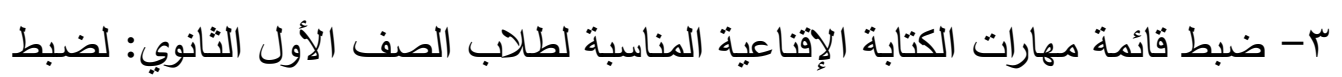

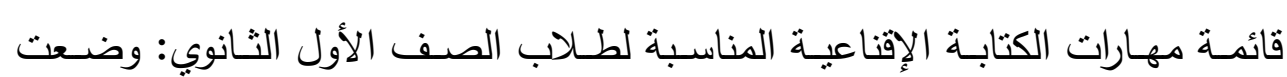


القائمة في صورتها المبدئية، وتكونت من عشر مهارات، وقد عرضت القائمسة على

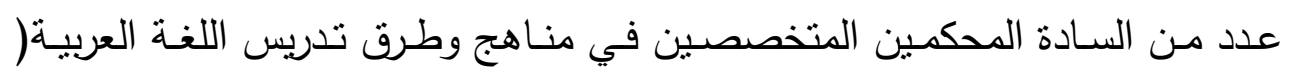

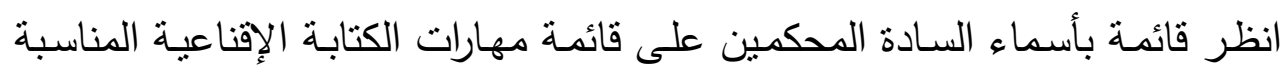
لطلاب الصف الأول الثانوي ملحق رقم ()، وقد أجرى الباحث عددًا من المقابلات مع السادة المحكمين، وتمت مناقثتهم في آرائهم حول مهارات الكتابة الإقناعية، وقد أجرى الباحث تعديلات على القائمة التي وضعها في ضوء ضوء المناقنـات التي تم

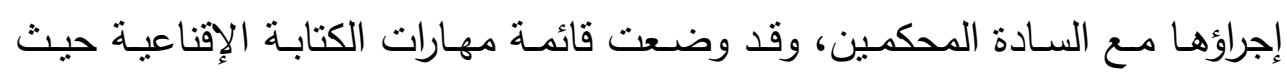
تضمنت انتتي عشرة مهارة في صورتها النهائية( ملحق رقم r).

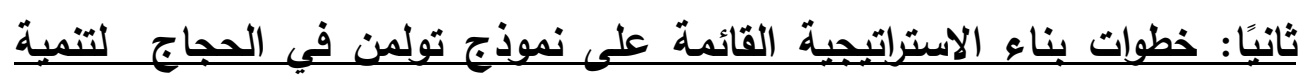

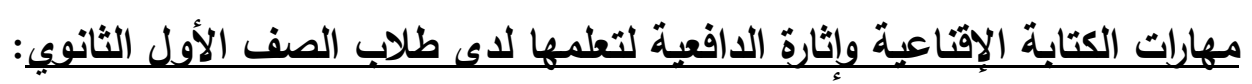
سار البحث الحالي في الخطوات التالية لبناء الاستراتيجية:

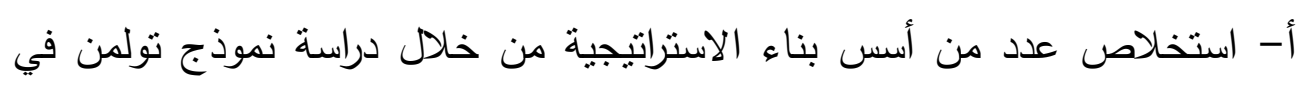
الحجاج ، وتم عرض هذه الأسس من خلال الإطار النظري للبحث.

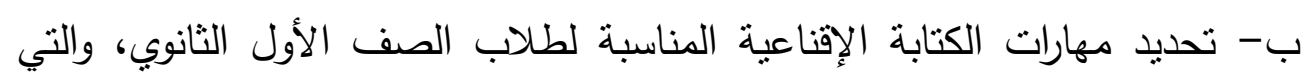
حددت من خلال هذا المحور . ج- وضع خطوات الاستراتيجية في ضوء الخطوتين السابقتين. ثالثًا: وصف الاستراتيحية القائمة على نموذج تولمن في الحجاج لتنمية مهاريات الكتابة الإقناعية وإثارة الدافعية لتعلمها لدى طلاب الصف الأول الثانوي: - تسير الاستراتيجية القائمة على نموذج الحجاج لنتمية مهارات الكتابة الإقناعية وإثارة الدافعية لتعلمها لدى طلاب الصف الأول الثانوي وفق خطوات منتابعة، كما

المرحلة الأولى: التمهيذ(التخطيط لكتابة نص إقناعي): في هذه المرحلة يقوم المعلم بعدة خطوات تتضمن ما يلي: - - يقسم الطلاب إلى مجموعات صغيرة. - يوجه الطلاب لاختيار القضية الجدالية التي سوف يكتبون حولها ـ 
- - يوزع على الطلاب نموذج استرشادي يوضح لهم كيفية السير في كتابة النص الإقناعي، وما يجب توافره في النص، وكيف يمكن تقييمهر وفق خطوات الاستراتيجية المقترحة. - يوضح للطلاب أن النص الإقناعي يتألف من مقدمة ومتن وخاتمة. المرحلة الثانية: كتابة الادعاءات والحجج المضادة : في هذه المرحلة يقوم المعلم بعدة خطوات تتضمن ما يلي: - - يوجه الطلاب إلى توليد الحجج المؤيدة للقضية المطروحة. - - يوجه الطلاب إلى جمع البيانات والمعلومات التي تدعم ادعائهم حول القضية المطروحة من وجهة نظرهم. - يوجه الطلاب إلى تحديد الأدلة التي تدل على صحة هذا هذا الادعاء. - يوجه الطلاب إلى تحديد المبررات التي تثبت صحة الادعاء. - - يتشارك مع الطلاب للوصول إلى كتابة الادعاءات في ضوء العناصر المتقق عليها، ونقد الحجج المضادة؛ ففي هذه المرحلة يقرر الطلاب ما إذا كانت البيانات التي جمعوها مناسبة وكافية ومقنعة. المرحلة الثالثة: المناقشة التأملية: وفي هذه المرحلة: - - يتيح المعلم الفرصة للطلاب لعرض ما توصوا إليه حول الادعاءات.

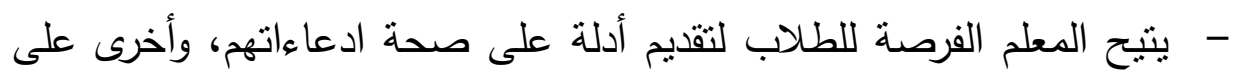

$$
\text { الانتقادات التي توجه إلى حججهم. }
$$

- - تتاقش كل مجموعة واحدة من الحجج المضادة، وتقديم أدلة دحضها. - - يوجه المعلم الطلاب إلى تقديم مزيد من الأدلة التي تدعم صحة ادعاءاتهم

$$
\text { في مقابل الانتقادات إن وجدت. }
$$

المرحلة الرابعة: إنتاج نص إقناعي: وفي هذه المرحلة:

- - يقوم الطلاب بكتابة النص الإقناعي في صورته المبدئية، ويرشدهم المعلم إلى أنه يتكون من مقدمة تتضمن تعريفًا بالقضية، ورأي الفريق فيها، ومتن يتضمن ثلاث فقرات على الأقل تتتاول الأدلة التي جمعت لتأكيد رأي الفريق، 
مع تفنبد الآراء المعارضة، وخاتمة تتضمن تلخيصًا لقضية النص، ورأي الفريق فيها، وإثبات صحتها.

- يقوم الطلاب بعرض النصوص الإقناعية على بعضهم البعض، وإجراء التعديلات المناسبة عليه. - - يقوم المعلم بتقديم التغذية الراجعة؛ لتقويم كتابات الطلاب، والحكم على جودة النصوص الإقناعية. - يقوم الطلاب بتعديل كتاباتهم، وتصويبها وفق التخذية الراجعة. - يقوم الطلاب بكتابة النص الإقناعي في صورته النهائية، ونشره في صحيفة المدرسة أو على موقعها الإلكتروني.

لإيعًا: تقويم مهارات الكتابة الإقناعية والدافعية لتعلمها لدى طلاب الصف الأول الثانوي:

اعتمد البحث الحالي على أداتين لتقوبم مهارات الكتابة الإقناعية والدافعية لتعلمها ، وهما على الترتيب اختبار مهارات الكتابـة الإقتاعية ، ومقياس الدافعيـة نحو تعلم الكتابة الإقناعية لدى طلاب الصف الأول الثانوي، وبيان ذلك تفصيلاً كما يلي: 1- اختبار مهارات مهارات الكتابة الإقتاعية لطلاب الصف الأول الثانوي:

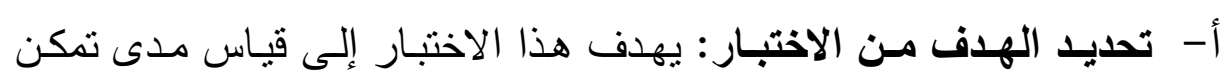
طلاب الصف الأول الثانوي من مهارات الكتابة الإقناعية ، والتي تم التوصل إليها في الخطوة السابقة. ب- مصـادر إعداد الاختبـار:تم إعداد هذا الاختبـار بالاعتمـاد على عدد مـن المصادر المتنوعة؛ والتي تمثلت فيما يأتي:

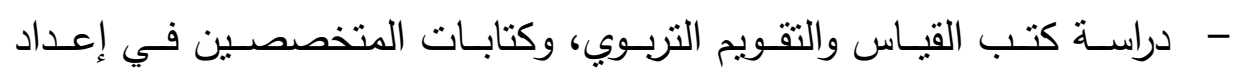
الاختبارات بأنواعها.

- - دراسـة وثنيقة المستويات المعياريـة لتعليم اللغـة العربيـة الصـادرة عن الهيئة القومية لضمان جودة التعليم والاعتماد( 9 . . ب) والخاصة بتعليم الكتابة. - - دراسة وتحليل الدراسات والبحوث السابقة في هذا المجال. 
ج- خطوات وضـع الاختبار : تم وضع اختبار الكتابـة الإقتاعية لدى طلاب الصف الأول الثانوي وفق الخطوات التالية:

الخطوة الأولى: صياغة الاختبار تكون الاختبار في صورته أولية من سؤالين ، يندرج تحت كل سـؤال موضـوعان ، ويختار الطالب موضـوعًا واحدًا فقط في كل سؤال للكتابة فيه ، وجاءت الأسئلة على شكل مقال.

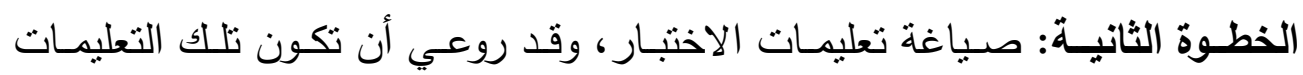
واضحة ومفهومة للطلاب. الخطوة الثالثة: ضبط الاختبار : بعد الانتهاء من إعداد الاختبار في صورته الأولية، وصياغة تعليماته تم عرضـه على مجموعة من المحكمين(انظر ملحق رقم( ())، وقد طلب منهم الحكم على: مناسبة الموضوعات لطلاب الصف الأول الثانوي، ،

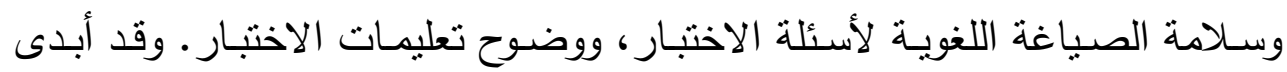

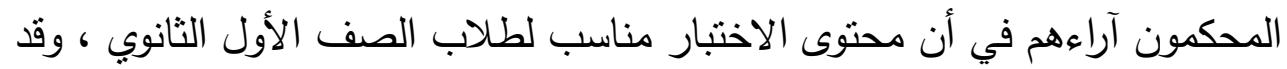

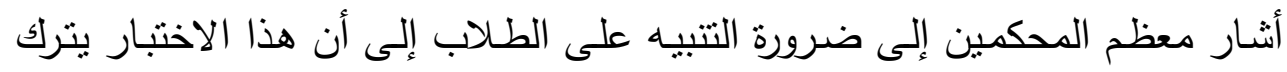

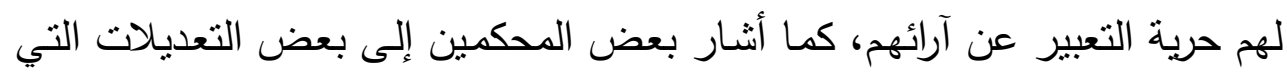
تم الأخذ بها. (ملحق رقم(r) يوضح اختبار مهارات الكتابة الإقناعية). الخطوة الرابعة: تصحيح الاختبار: تحديد درجة استجابة الطلاب على أسئلة الاختبار ؛ ومن أجل ذلك تم إعداد وصف لمستويات الأداء Rubrics من خلال مجموعة من المعايير الثابتة التي لا تخضع لذاتية المصحح واجتهاده الثخصي. وتنكونت الأداة في صورتها المبدئية من أربعة مستويات متدرجة هي (متمكن - مرضٍ - نام - متعثر) ، والدرجة الكلية المخصصة لكل مستوى على الترتيب من الأعلى إلى الأدنى هي(به هـ

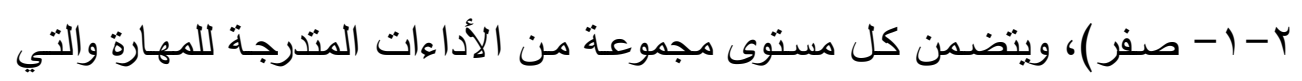
حدد في ضـوئها مستوى أداء الطالب للمهارة ووضعت الدرجـة المستحقة لـه تمهيدًا لإجراء المعالجات الإحصائية، والحكم على مسنتوى أداء الطالب في الاختبار كله، ولضبط الأداة تم عرضـها على عدد من المحكمين، واتفقوا على صـلاحيتها لتصحيح

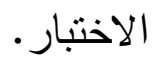


د - تحديد ثبات الاختبار : ولحساب الثبات ثم تطبيق الاختبار على عينة من طلاب الصف الأول الثانوي مكونـة من (0ب) طالبًا وطالبـة بمدرسـة جمال عبد الناصر الثانوية الرسمية لغات بإدارة الدقي التعليمية ، وتم رصد الدرجات باستخدام المقياس

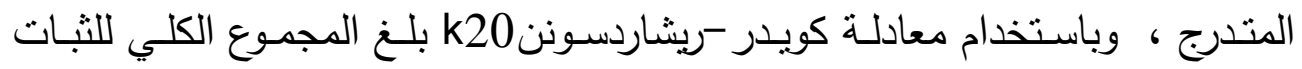
للمهارات ؟ 9 , · وهو معامل ثبات مرتفع؛ مما يشير إلي إمكانية تطبيق الاختبار ميدانيًا. -كما تم حساب زمن الاختبار من خلال منتسط الزمن الذي استغرقه كل الطلاب في

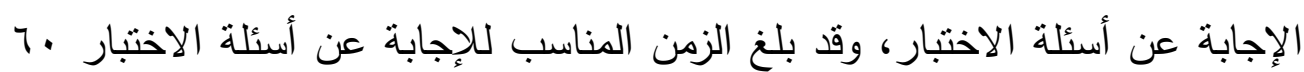
دقيقة.

\section{r- مقياس الدافعية نحو تعلم الكتابة الإقتاعية :}

أ- الهدف من بناء المقياس: هدف المقياس إلى تحديد فاعلية الاستراتيجية التي يقدمها البحث الحالي في إثارة الدافعية لتعلم الكتابة الإقناعية لدى طلاب الصف الأول الثانوي، وعلاقتها الارتباطية بمتغير مستوى الطلاب في مهارات الكتابة الإقناعية.

ب- خطوات وضع المقياس: نم وضع مقياس الدافعية نحو تعلم الكتابة الإقناعية وفق الخطوات التالية: - (النية

الخطوة الأولى: تقسيح المقياس إلىى ثلاثة جوانب وفقًا لموئثرات الافعية نحو تعلم الكتابة الإقناعية التي تم التوصل إلبها سابقًا، وهي: الجانب الأول: الجانب المعرفي، والجانب الثاني: الجانب الوجداني، والجانب الثالث: الجانب السلوكي. الخطوة الثانية: صباغة بنود المقياس: وتم ذلك من خلال التعبير عن الدافعية نحو تعلم الكتابة الإقناعية في صورة جمل تقريرية ذاتية. الخطوة الثالثة: تحدب مستويات استجابات الطلاب، وهي: دائمًا وتأخذ ( ع)، وغالبًا

$$
\text { وتأخذ(r)، وأحيانًا وتأخذ(ب)، ونادرًا وتأخذ( ( ). }
$$


الخطوة الرابعـة: صـياغة تعليمـات المقبـاس، وقد روعي أن تكون تلك التعليمات واضحة ومفهومة للطلاب. الخطوة الخامسة: ضبط المقياس وقد تم ذللك من خلال وضع المقياس في صورة مبدئية على مجموعة من السادة المحكمين في مناهج وطرائق تدريس اللغة العربية، وعلم النفس التربوي(انظر ملحق رقم( () يوضح أسماء السادة المحكمين ووظائفه)، وقد طلب منهم الحكم على: مناسبة مفردات المقياس للدافعية نحو تعلم الكتابة الإقناعية، وصياغة عبارات المقياس لغويًا، ووضوح تعليمات المقياس، وإضافة ملاحظات أخرى يرون إضافتها للمقياس. وقد عقد الباحث مع السادة المحكمين عدة جلسات لمناقثة الآراء التي تفضل بها يهات

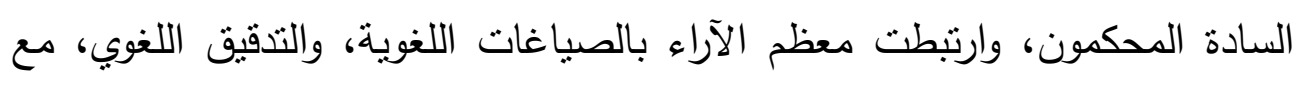

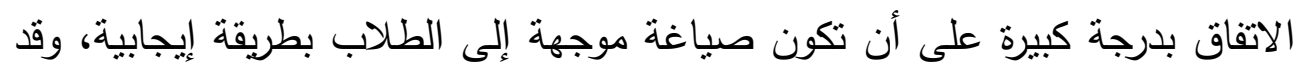

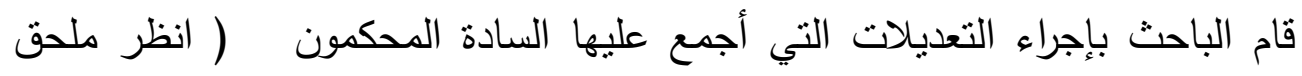
رقم(؟) يوضح مقياس الدافعية نحو تعلم الكتابة الإقناعية). الخطوة الخامسة: التجربة الاستطلاعية للمقياس: أجرى الباحث دراسة استطلاعية على المقياس بهدف:

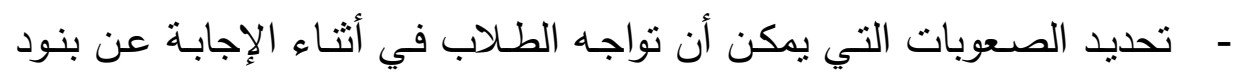
المقياس. - ت تحديد زمن اللازم للإجابة عن بنود المقياس. وقد تم تطبيق التجربة الاستطلاعية للمقياس على عينة عثوائية عددها (rv) طالبًا وطالبة بالصف الأول الثانوي بمدرسة جمال عبد الناصر الثانوية الرسمية لغات بإدارة الدقي التعليمية، وقد أسفرت التجربة الاستطلاعية عن النتائج التالية: الصياغة اللغوية لبنود المقياس تتاسب طلاب الصف الأول الثانوي. يتحـد زمـن الإجابـة عـن أسـلة المقيـاس مـن خـلال المعادلـة التاليـة (علي خطـاب، $:(r+1)$ 
زمن المقياس = زمن أول طالب ينهي الإجابة عن أسئلة المقياس+ زمن آخر طالب ينهي الإجابة عنه

r

ويكون زمسن المقياس هو • دقيقة، وتضـاف خمس دقائق إلى هذا الزمن لقراءة التعليمات. تحديد ثبات المقياس: لحساب ثبات المقياس تم استخدام معادلة معامل ألفا كرونباخ، ويوضح الجدول رقم(1) التالي معاملات ثبات مقياس الدافعية لتعلم الكتابة الإقناعية. - ثبات مقياس الدافعية نحو تعلم الكتابة الإقناعية: لحساب الثبات تم نطبيق المقياس على عينة عشوائية عددها VY) طالبًا وطالبة بالصف الأول الثانوي بمدرسة جمال عبد الناصر الثانوية الرسمية لغات بإدارة الدقي التعليمية مرتين (بفاصل زمني أسبوعين)، وباستخدام معامل الارتباط ، جاءت النتائج كما يلي: جدول( (1) ثبات مفردات مقياس الدافعية نحو تعلم الكتابة الإقناعية

\begin{tabular}{|c|c|c|c|}
\hline معامل ارتباط بيرسون & عدد المفردات & المحاور الفرعية للمقياس & \multirow{5}{*}{ الدافعية نحو تعلم اللغة العربية لمقية المبية } \\
\hline$\cdot, \wedge \cdot 1$ & 10 & الجانب المعرفي & \\
\hline$\cdot, T \vee T$ & $\varepsilon$ & الجانب الوجداني & \\
\hline$\cdot, 7 \wedge 1$ & 0 & الجانب السلوكي & \\
\hline$\cdot, \wedge \vee Y$ & $r \varepsilon$ & إجمالي & \\
\hline
\end{tabular}

ويتضح من جدول( (1) السابق أن قيم معامل ارتباط بيرسون موجبة وبدرجة قوية، ودالة إحصائيًا عند مسنتى أقل من أو يساوي (1 •.,·)، مما يعني أن مفردات المقياس تتسم بالثبات بدرجة مقبولة على مستوى كل محور، ومستوى مقياس الدافعية نحو تعلم الكتابة الإقناعية بصفة ككل؛ مما يشير إلى إمكانية تطبيق المقياس ميدانيًا. خامسًا: دليل المعلمـ : ويهدف دليل المعلم إلى تقديم إرشادات وتوجيهات لمعلم اللغة العربية بالصف الأول الثانوي لاستخدام الاستراتيجية التي يقدمها البحث الحالي، وذلك

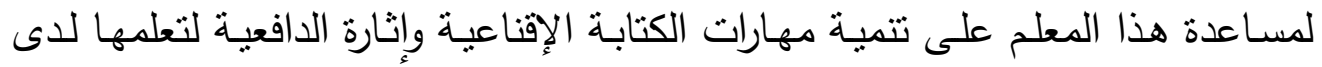
طلاب الصف الأول الثانوي، وقد تضمن الدليل الذي يقدمه البحث الحالي كلًا من: 
- مهارات الكتابة الإقناعية التي يسعى البحث الحالي لتتميتها لدى طلاب الصف الأول الثانوي. - الاستراتيجية القائمسة على نظرية تولمن في الحجاج لتتمية مهارات الكتابة الإقناعية ،

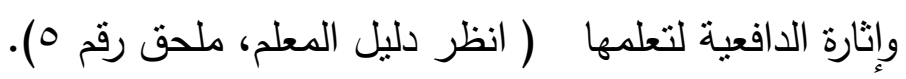
تطبيق الاستراتيجية القائمة على نموذج تولمن في الحجاج لتنمبـة مهارات الكتابـة الإقتاعية وإثارة الدافعية لتعلمها لدى طلاب الصف الأول الثانوي: ويتضمن هذ المحور كلاً مما يلي:

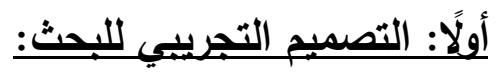
تم اختيار مجموعة البحث ( المجموعة التجريبية) من طلاب الصف الأول الثانوي بمدرسة جمال عبد الناصر الرسمية لغات بإدارة الدقي التعليمية بلغ عددها(rV) طالبًا وطالبة يتم تطبيق الاستراتيجية الذي يعتمدها البحث الحالي عليهم ؛ حيث اعتمد البحث الحالي على التصميم التجربي ذي المجموعة الواحدة.

ثثانيًا: التطبيق القبلي لاختبار مهارات الكتابة الإقتاعية ومقياس الدافعية لتعلمها : وقد تم تطبيق اختبار مهارات الكتابة الإقناعية ، ومقياس الدافعية لتعلمها على

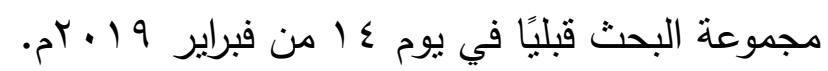

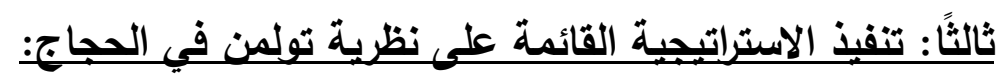

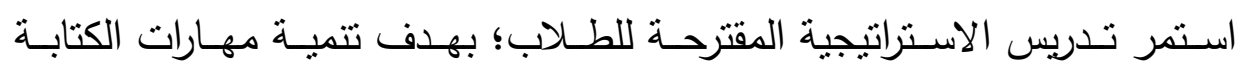

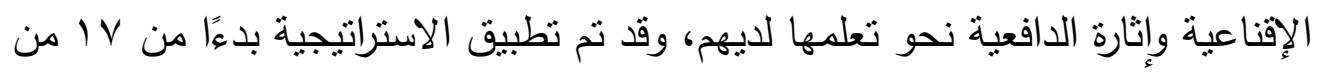

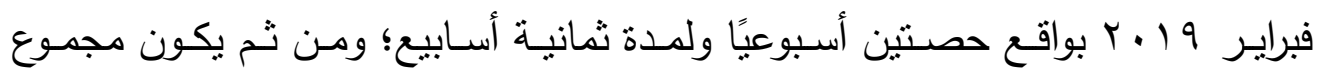

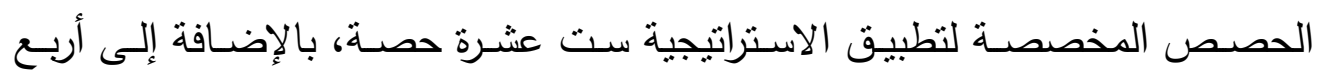
حصص للتقويم القبلي والبعدي، حيث قام معلم اللغة العربية بتوظيف حصص القراءة متحررة المحتوى، وحصص التعبير الكتابي لتدريب طلاب المجموعة التجربيية ، من لن خلال بعض الموضوعات والقضايا الجدلية التي حظيت باهتماماتهم، وفق استطلاع الرأي الذي قدمه الباحث إلبهم ، وهي:( مواقع التواصل الاجتماعي، والإجازة الدراسية

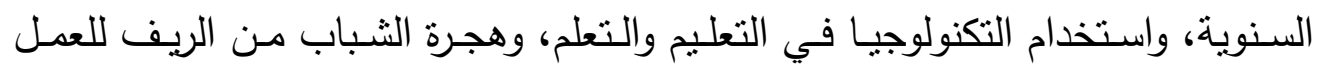


بالمــن، والألعـاب الإلكترونيـة، والوجبـات السـريعة، والصــافة الورقيـة أم الصـحافة الإلكترونية، والأنشطة والمعسكرات الصيفية)، والجدول التالي يوضـح الجدول الزمني

لتنفيذ الاستراتيجية:

جدول (r) الجدول الزمني لتتفيذ الاستراتيجية القائمة على نظرية تولمن في الحجاج

\begin{tabular}{|c|c|c|c|}
\hline الحصص عدد & والقضايا الجدلية & مهارات الكتابة الإفناعية المستهدف تتمينها & مراحل الاستراتيجية \\
\hline حصص أربع & الإجنماعي- الإزة الدراسية & 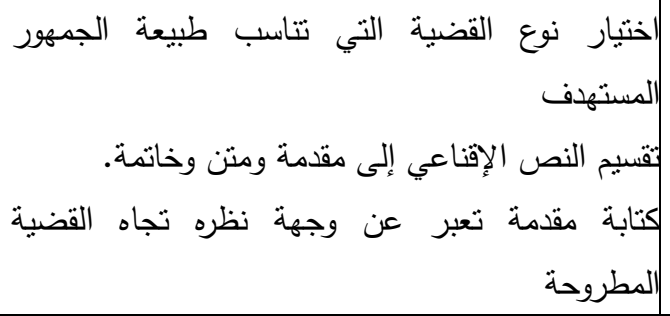 & 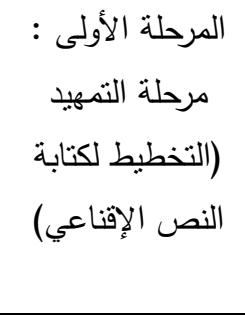 \\
\hline حصص & 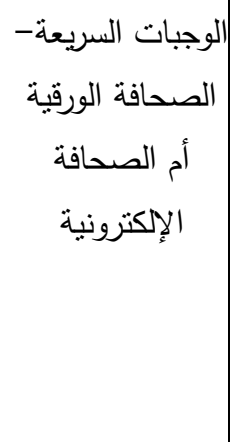 & 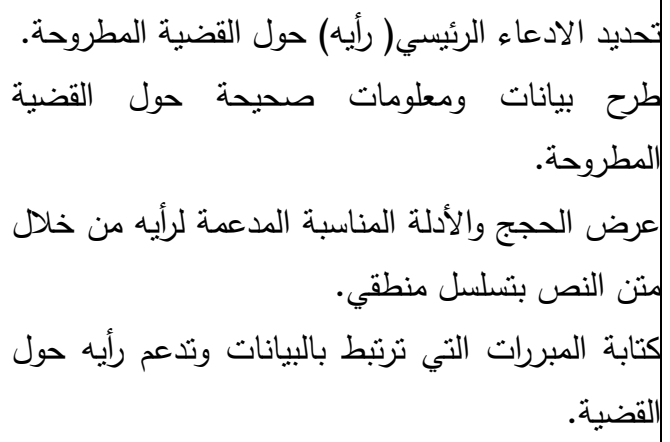 & الادرحلة الثاءلة كتابة: \\
\hline حصص أربع & 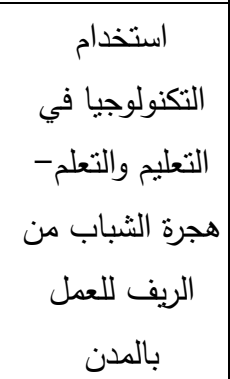 & تاتقبيم وجهات النظر المعارضة لرأيه بدقة (الادعاءات & المرحلة الثالثة : \\
\hline حصص أربع & $\begin{array}{c}\text { الإلكترونية - الألثاب } \\
\text { المعسكرات } \\
\text { الصفية }\end{array}$ & 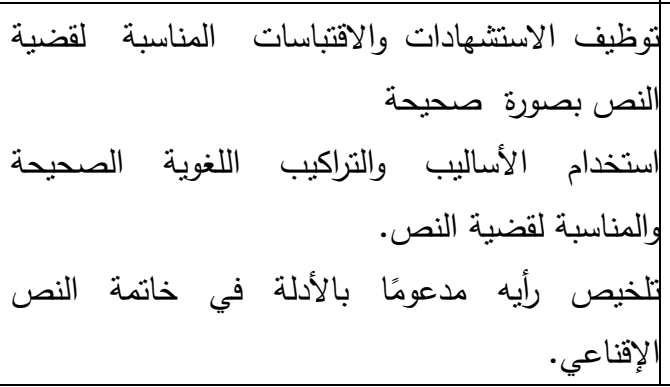 & مرحلة إنتاج نص \\
\hline
\end{tabular}




\begin{tabular}{|c|c|c|c|}
\hline المجموع & الثتا عشرة مهارة & \\
\hline
\end{tabular}

وقد تم تدريس الاستراتيجية للطلاب مجموعة البحث( المجموعة التجريبية) من خلال

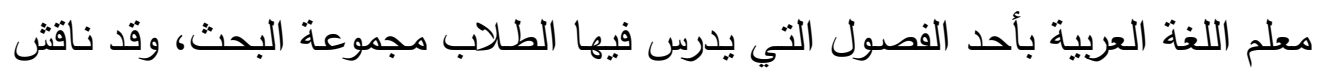

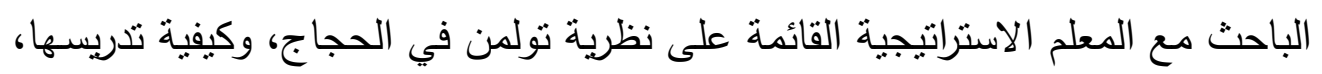

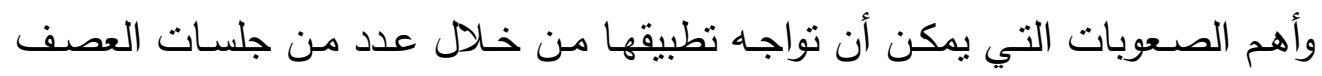
الذهنى، وكذلك نـاقش معـه الباحث دليـل المعلم، وكيفيـة الاسـتفادة منـه في تـدريس الاستراتيجية.

\section{لإيعًا: التطبيق البعدي لأدوات التقوبيم:}

تم تطبيق اختبار مهارات الكتابـة الإقتاعيـة ومقياس الدافعية نحو تعلم الكتابـة

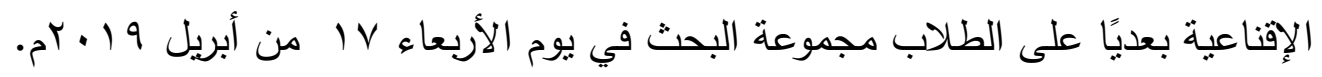
خامسًا: المعالجة الإحصائبة للنتائج: تم حسـاب قيمـة "ت" لدراسـة الفروق بين التطبيقن القبلي والبعدي؛ لمقارنـة نتائج مجموعة البحث قبل تدريس الاستراتيجية وبعدها؛ للتأكد من فاعليتها في تتمية مهارات

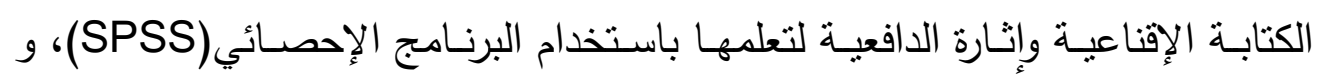

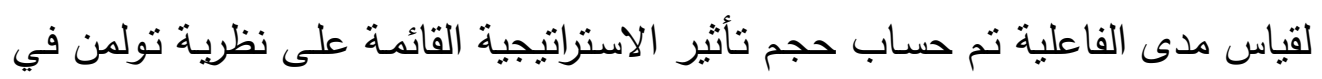

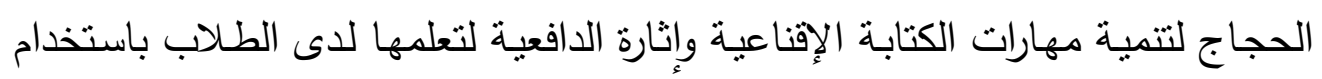

$$
\begin{aligned}
& \text { حساب مربع إيتا من خلا المعادلة التالية ( سيد عبد الرحمن، } 9 \text {. . ץ): }
\end{aligned}
$$

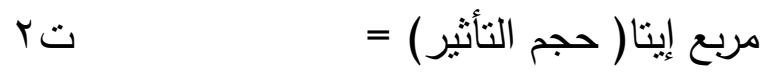

$$
\begin{aligned}
& \dot{u}+r \dot{ت}
\end{aligned}
$$

\section{سادسًا:نتائج البحث وتفسيرها ومناقشتيها}

للإجابة عن السؤال الرابع، والذي نصسه:"ما فاعلية الاستراتيجية القائمـة على نموذج

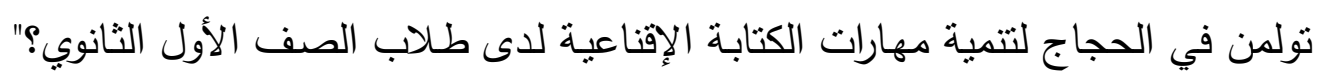
من اختبار صحة الفرض التالي:" توجد فروق ذات دلالة احصائية عند مستوي دلالة

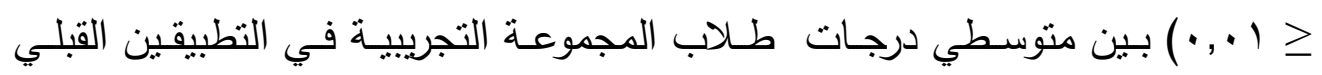


والبعدي لاختبار مهارات الكتابة الإقناعية بصفة عامة، ومهاراتها كل علي حدة لصالح التطبيق البعدي." ولدراسة دلالة الفروق بين النطبيقين القبلي والبعدي، تم استخدام اختبار(ت)، وكانت النتائج كما في جدول (ب) كما يلي:

جدول(r) نتائج اختبار (ت) للفروق بين متوسطي درجات طلاب المجموعة التجريبية في التطبيقين القبلي والبعدي لاختبار الكتابة الإقناعية بصفة عامة ومهاراته كل على حدة

\begin{tabular}{|c|c|c|c|c|c|c|c|c|}
\hline \multirow[t]{2}{*}{ الدالة } & \multirow[t]{2}{*}{ | الحرية } & \multirow[t]{2}{*}{ قيمة (ت) } & \multirow[t]{2}{*}{ الارنباط } & \multicolumn{2}{|c|}{ الانحراف } & \multicolumn{2}{|c|}{ الوسط الحسابي } & \multirow[t]{2}{*}{ المهارات } \\
\hline & & & & بعدي & قبلي & بعدي & قبلي & \\
\hline دالة & ro & r..人rA & $\ldots v r$ &.. $\mathrm{rA}$ & - & r.9Y & 1.00 & كتابة مقدمة تعبر عن \\
\hline دالة & ro & $r q .1 . r$ & $\ldots \wedge 4$ & . &.$T_{1}$ & r.90 & 1.11 & تقلىيم النص الإقناعي \\
\hline دالة & ro & $10 . .0$. & $.1 r_{0}$ & .0. &.$\Upsilon \uparrow \Lambda$ & $r . \varepsilon r$ & $1 . .1$ & 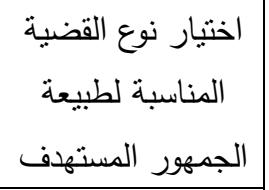 \\
\hline دالة & ro & $r . .1 r_{1}$ & $\ldots \times 1$ & . ro & . & r.AT & $1.1 \varepsilon$ & الرئيسي( رأيه) حول الادعاء \\
\hline دالة & ro & $19 \ldots 1$ & $\ldots .01$ &..$Y \wedge$ &. $.1 \mathrm{~V}$ & r... & $1 . . r$ & 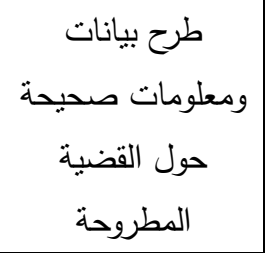 \\
\hline دالة & ro & r..9T & . TRT &. $.1 \mathrm{~V}$ &.+4 & r.qV & 1.15 & |المناسبة المدعمة لرأيه \\
\hline
\end{tabular}




\begin{tabular}{|c|c|c|c|c|c|c|c|c|}
\hline & & & & & & & & من خلال متن النص \\
\hline دالة & ro & 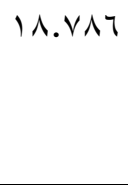 & $\cdot . \leqslant Y$ &.$r \varepsilon$ & rr. & r.10 & $1 . .7$ & كتابة المبررات التي \\
\hline دالة & ro & $1 \wedge . \vee 7$. & $\because \leqslant 9$ & .17 & .07 & T.9V & $1.1 \mathrm{~V}$ & القديم وجهات النظر \\
\hline دالة & o r & $1 \cdot . \leqslant 0 V$ & .Y Y V & .0. & $\cdot . \leqslant r$ & T.OS & $1 . M r$ & تلفيد الآراء المضادة بدقة ودحضها \\
\hline دالة & o ro & $1 \cdot . \leq \leq r$ & $. r \leq 1$ & $\cdot . \leqslant V$ & $\because V 7$ & T.TA & $1 . r q$ & الصتخدام الأساليب \\
\hline دالة & ro & $1 . V \mid V$ & $.19 \vee$ & וT & $\therefore \Lambda$. & r. 19 & $1 . \varepsilon \varepsilon$ & توأليف الاقتشهادات لتدعيم في القضية \\
\hline دالة & ro & $\vee . \wedge \vee \wedge$ & דrV &.$r V$ & $\because V 7$ & Y.A乏 & $1 . \leqslant Y$ & تلخيص رألأدلة في مدعومًا \\
\hline دالة & o ro & r & מזT. & $1 . \varepsilon$. & r.7. & r. .9A & $1 \leqslant . V \varepsilon$ & إجمالي \\
\hline
\end{tabular}

يتبين من الجدول(r) السابق وجود فروق ذات دلالة إحصائية عند مستوى ا +...، بين متوسطس درجات طلاب المجموعة التجريبية في التطبيقين القبلي والبعدي لصالح التطبيق البعدي، مما يشير إلي قبول الفرض، وللتأكد من فاعلية الاسترتيجية المقترحة في تتمية مهارات الكتابة الإقناعية تم حساب حجم التأثنر ، ويلاحظ كبر حجم التأثير؛ مما يدل على وجود أثز للمتغير المستقل ( الاستراتيجية المقترحة) في تتمية المتغير التابع ( الكتابة الإقناعية). 
وتُعَى هذه النتيجة إلى تدريب الطلاب من خلال الاستراتيجية المقترحة القائمة على نموذج نولمن في الحجاج، ومشاركتهم الفاعلة في أنتاء تطبيقها؛ فقد سارت هذه الاستراتيجية وفق خطوات متتابعة تسمح للطالب بالتثريب على الكتابة الإقناعية، والتمكن من مهاراتها، حيث تساعد مرحلة التمهيد( التخطيط لكتابة النص الإقناعي) في اختيار القضية التي تلائم الجمهور المستهدف، وتحديد خطواته، وتقسيمه إلى مقدمة ومتن وخاتمة، وتساعد المرحلة الثانية: مرحلة كتابة الادعاءات والحجج المضادة في: تحديد الادعاء الرئيسي( رأيه) حول القضية المطروحة، وطرح بيانات ومعلومات صحيحة حول القضية المطروحة، وعرض الحجج والأدلة المناسبة المدعمة لرأيهر من خلال منن النص بتسلسل منطقي، وكتابة المبررات التي ترتبط بالبيانات وتدعم رأيهم حول القضية، وتساعد المرحلة الثالثة: مرحلة المناقشة التأملية في: تقديم وجهات النظر المعارضة لرأيه بدقة (الادعاءات المضادة)، وتفنيد الآراء المضادة لآرائهم بدقة ودحضها بوضوح، أما المرحلة الرابعة: إنتاج نص إقناعي، فتساعد في: توظيف الاستشهادات والاقتباسات المناسبة لقضية النص بصورة صحيحة، واستخدام الأساليب والتراكيب اللغوية الصحيحة والمناسبة لقضية النص، وتلخيص آرائهم مدعومًا بالأدلة في خاتمة النص الإقناعي، وهذه النتيجة تتفق مع ما أثنارت إلبه دراسة (Hormazabal, R. D. 2007) التي أثنارت إلى أن كتابة النص الإقناعي يتطلب تدريب الطلاب على بناء الادعاءات، ودعمها بالأدلة، والمبررات التي تمكنهم من إقناع الآخرين بسهولة، وهذا ما ركزت عليه الاستراتيجية بالبحث الحالي في المرحلة الثانية، ودراسة ( Johnson,T.,2012) التي أوضحت أن بناء الأدلة، وكتابة المبررات التي تدعم الادعاءات حول القضية المطروحة، يمكن الطلاب من تتظيم النص الإقناعي، وهذا ما عززته الاستراتيجية، على مستوى التخطبط والتتفيذ. كما تتفق مع نتائج دراسة(Zainuddin Z., S. \& Rafik-Galea, S. 2016) حيث أكدت أن تتمية مهارات الكتابة الإقناعية تتطلب تضمينها كجزء من أنشطة التعليم والتعلم، وتحديد نواحي القصور والتذريب عليها، وهذا ما ركزت عليه 
الاستراتيجية في المرحلتين الثالثة والرابعة؛ مما كان له تأثثر واضح في إنجاز الطلاب في كتابة النصوص الإقناعية بصورة صحيحة. ولإجابة عن السؤال الخامس، والذي نصد:"ما فاعلية الاستراتيجية القائمة على نموذج تولمن في الحجاج لإثارة الدافعية لتعلم الكتابة الإقناعية لدى طلاب الصف الأول الثانوي؟" تم اختبار صحة الفرض التالي:" توجد فروق ذات دلالة احصائية عند مستوي دلالة ( 1 ( +., •) بين متوسطي درجات طلاب المجموعتين التجريبية في التطبيقين القبلي والبعدي لمقياس الدافعية نحو تعلم الكتابة الإقناعية بصفة عامة، ومحاورها كل علي حدة لصالح التطبيق البعدي". ولدراسة دلالة الفروق بين التطبيقين القبلي والبعدي، تم استخدام اختبار(ت)، وكانت النتائج كما في جدول (ع) كما يلي:

جدول(§) نتائج اختبار (ت) للفروق بين متوسطي درجات طلاب المجموعة التجربيية في التطبيقين القبلي والبعدي لمقياس الدافعية نحو تعلم الكتابة الإقناعية بصفة عامة

\begin{tabular}{|c|c|c|c|c|c|c|c|c|}
\hline \multirow[t]{2}{*}{ الدالة الد } & \multirow[t]{2}{*}{ درجات } & \multirow[t]{2}{*}{ قيمة (ت) } & \multirow[t]{2}{*}{ الارتباط معامل } & \multicolumn{2}{|c|}{ الانحراف } & \multicolumn{2}{|c|}{ الوسط الحسابي } & \multirow[t]{2}{*}{ أبعاد المقياس } \\
\hline & & & & بعدي & قبلي & بعدي & قبلي & \\
\hline دالة & ro & YI.人TV & .YYA & $\varepsilon .17$ & 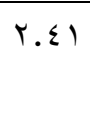 & $0 . . v$. & M. & أولاً: الجانب \\
\hline دالة & ro & דזד. 1י & $. r \leqslant V$ & . & $1 . . \varepsilon$ & $1 T . \varepsilon r$ & $v .79$ & ثانيًا: الجانب \\
\hline دالة & ro & 17.199 & .00 & $1 . V T$ & 1.89 & $11 . r 0$ & 11.11 & ثالثًا: الجانب \\
\hline دالة & ro & rT.r.q & צות. & $7 . \cdot \varepsilon$ & r.AT & $\Lambda Y .\{\Lambda$ & $0 . .79$ & إجمالي \\
\hline
\end{tabular}

يوضح جدول (ع) السابق وجود فروق ذات دلالة إحصائية عند مستوى الـ ا... بين المتوسطات الحسابية لدرجات طلاب المجموعة التجريبية، وجاءت هذه الفروق لصالح متوسطات درجات طلاب المجموعة التجريبية في التطبيق البعدي لمقياس 
الدافعية نحو تعلم الكتابة الإقناعية بصفة عامة، ومحاوره كل علي حدة. ولحساب فاعلية الاسترتيجية المقترحة في إثارة الدافعية نحو تعلم الكتابة الإقناعية تم حساب حجم

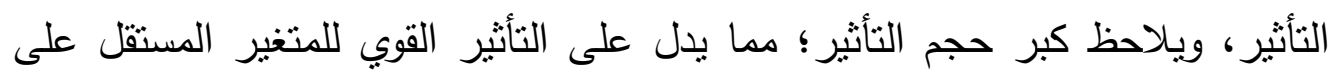
المتغير التابع، وتتضح فاعلية الاستراتيجية القائمة على نموذج تولمن في الحجاج في إثارة الدافعية نحو تعلم الكتابة الإقناعية بصفة عامة، وبالتالي يتم قبول الفرض. وتُعَى هذه النتيجة إلى أن استراتيجية التدريس المقترحة قد أتاحت مشاركة الطلاب لإبه لهابه

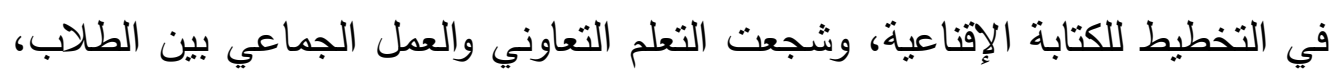
وعززت لديهم المشاركة الإيجابية عند كتابة النص الإقناعي، بالإضافة إلى تتويع المثيرات باستخدام الوسائط التعليمية المتعددة، وتوظيف التكنولوجيا في أثثاء عملية التعلم، وتتويع أساليب التدريس، مثل: العصف الذهني والحوار والمناقنة، وتتويع الأنشطة المستخدمة في أثناء التعلم، كما تضمنت الاستراتيجية ممارسات تدريسية أتاحت تزوبد الطلاب بنتائج أعمالهم فور الانتهاء منها، وتقديم التغذية الراجعة المستمرة في أثناء التعلم؛ مما كان له تأثنر كبير في إثارة الدافعية نحو تعلم الكتابة الإقناعية لدى الطلاب.

ولإجابة عن السؤال السادس، ونصه:" ما مستوى العلاقة الارتباطية بين درجات طلاب المجموعة التجريبية في مهارات الكتابة الإقناعية وإثارة الدافعية لتعلمها في التطبيق البعدي؟ تم اختبار صحة الفرض التالى" توجد علاقة ارتباطية موجبة ذو دلالة احصائية عند مستوي دلالة ( في التطبيق البعدي لاختبار مهارات الكتابة الإقناعية، ودرجاتهم في التطبيق البعدي لمقياس الدافعية نحو تعلم الكتابة الإقناعية بصفة عامة"، ولاختبار صحة الفرض تم

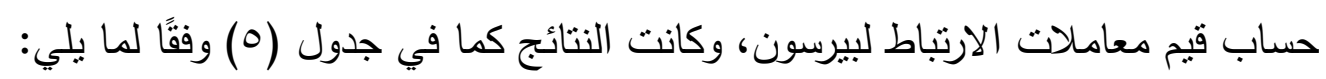
جدول (0) نتائج معامل ارتباط بيرسون بين درجات طلاب المجموعة التجريبية في التطبيق البعدي لاختبار مهارات الكتابة الإقناعية، ودرجاتهم في التطبيق البعدي لمقياس الدافعية نحو تعلم الكتابة الإقناعية بصفة عامة" لئهي 


\section{(السنة السابعة - العدد الثامن عشر - إيريل 9 ( م.rم)}

\begin{tabular}{|c|c|c|c|c|}
\hline 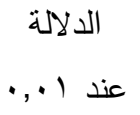 & نوع الارتباط & معامل & العينة & أبعاد العلاقة الارتباطية \\
\hline 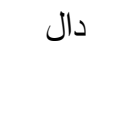 & موجب قوي & $.7 r 9$ & rV & الكتابة الإقناعية الكتابة الإقناعية × إثارة الدافعية لتعلم \\
\hline
\end{tabular}

يتضح من جدول(0) أن قيمة معامل الارتباط لبيرسون موجبة ، وتعنى وجود علاقة ارتباطية موجبة قوبة بين درجات طلاب المجموعة التجريبية في التطبيق البعدي لاختبار مهارات الكتابة الإقناعية، ومقياس الدافعية نحو تعلم الكتابة الإقناعية بصفة عامة، مما يدل على قبول الفرض. وتعزى هذه النتيجة إلى أن ارتفاع مستوى الطلاب في اكتساب مهارات الكتابة الإقناعية صاحبه إثارة الدافية نحو تعلمها؛ وذلك لأنه قد لوحظ أن الطلاب في أثناء تعلمهم الكتابة الإقناعية يقبلون على الكتابة دون تردد، ويشاركون بعضهم البعض في التخطيط لكتابة النص إقناعي، وينتلون بين خطوات الكتابة الإقناعية بيسر وسهولة، وبتعاونون مع زمالأهم في أثثاء كتابة النص الإقناعي، بالإضافة إلى استخدم اللغة العربية السليمة للتعبير عن أفكارهم وآرائهم، وتحسين كتاباتهم باستمرار في أثناء التعلم، وبذلك حدث علاقة بين تتمية مهارات الكتابة الإقناعية واثثارة الدافعية نحو تعلمها لدى عينة البحث.

\section{سابعًا: توصياث البحث:}

في ضوء مشكلة البحث، وما كثف عنه من نتائج بمكن تقديم التوصيات التالبة:

ا- - الإفادة من قائمة مهارات الكتابة الإقناعية التي تم التوصل إلبها لتدريب الطلاب عليها ، وتتميتها لديهم.

r- تدريب معلمي اللغة العربية بالمرحلة الثانوية على التذريس وفق الاستراتيجية المقترحة بالبحث الحالي لتنمية مهارات الكتابة الإقناعية وإثارة الدافعية لتعلمها لدى الطلاب.

ب- الإفادة من الموضوعات والقضايا الجدلية التي قدمها البحث، وتدريب طلاب الصف الأول الثانوي من خلالها لتتمية مهارات الكتابة الإقناعية لديهم. 
r- إعادة النظر في أدوات، ووسائل تقويم مهارات الكتابة الإقناعية، وإثارة الدافعية لتعلمها في ضوء الاختبار والمقياس اللذين يقدمها البحث الحالي.

ثامنًا: مقترحات البحث

ا - استراتيجية قائمة على نموذج تولمن في الحجاج لتتمية مهارات القراءة الجهرية والتفكير الناقد لدى طلاب المرحلة الثانوية. r- برنامج قائم على نموذج نولمن في الحجاج لتتمية مهارات التواصل اللغوي لدى طلاب المرحلة الثانوية. r- وحدة قائمة على نموذج تولمن في الحجاج لتتمية مهارات الخطابة والطلاقة الثفهية لدى طلاب المرحلة الإعدادية.

\section{المراجع}

- أشرف أحمد أبو حليمة(1) + ب). دافعية الإنجاز.عمان: دار المسيرة للنشر

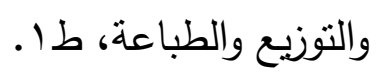

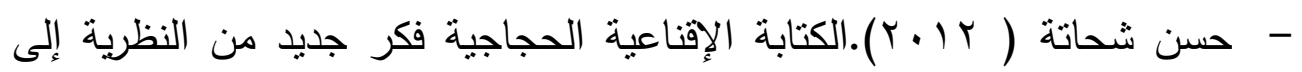
التطبيق. القاهرة: دار العالم العربي، ط ا.

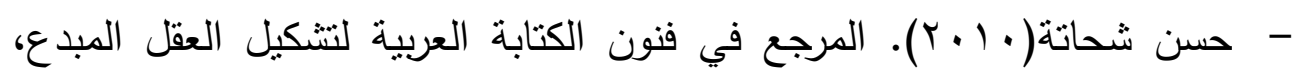
القاهرة:دار العالم العربي، طا ا. - حمد بن إبراهيم العثمان( ( . . ب). أصول الجدل والمناظرة في الكتاب والسنة. الكويت: مكتبة ابن القيم. - - داليا يوسف محمد( • • (ץ). فاعلية استراتيجية مقترحة في تتمية مهارات الكتابة الإقناعية لدى تلاميذ المرحلة الإعدادية. رسالة ماجستير. غير منشورة. كلية التربية. جامعة عين شمس. - دينا محمد محمد الحصي(0 10). نظرية الحجاج في المنطق غير الصوري

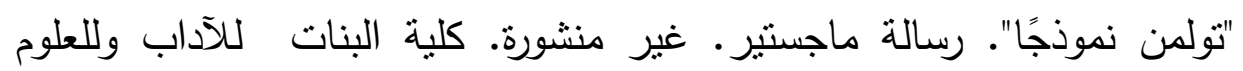
والتربية. جامعة عين شمس. 
- سعد عبد الرحمن(9 . . ץ).القياس النفسي( النظرية والنطبيق). القاهرة: دار الفكر

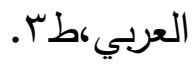

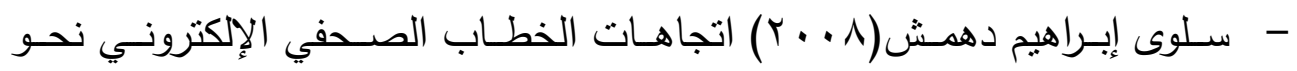

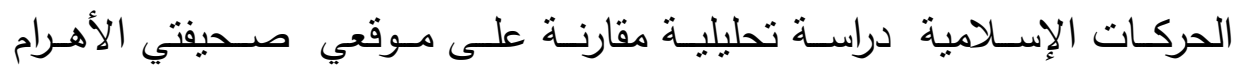
المصرية والهيرالدتربيون الدولية الأمريكية. رسالة ماجستير • غير منشورة. كلية الآداب. جامعة جنوب الوادي. قنا. - شوقي المصطفى( ( . . - الم). المجاز والحجاج في درس الفلسفة بين الكلمة والصورة. المغرب: دار الثقافة للنشر والتوزيع ، طه

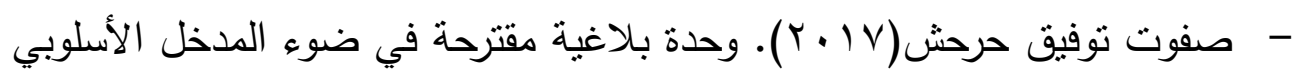

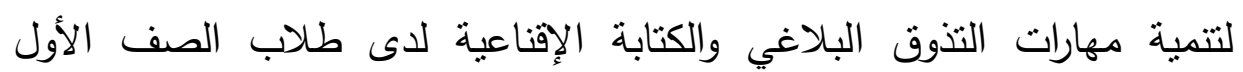
الثانوي. مجلة دراسات في المناهج وطرق التدريس. ع(Yr). مايو، ص ص ص $.70-17$

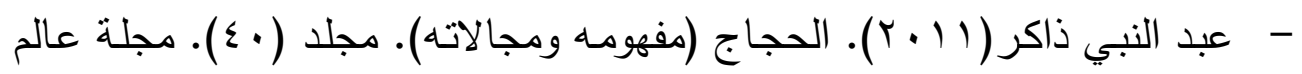
الفكر المجلس الوطني للثقافة والفنون والآداب: الكويت، أكتوبر • - علاء الدين حسن سعودي(V) • (Y). استخدام التعلم القائم على الاستقضاء في تتمية الكتابة الإقناعية والوعي بمهاراتها لدى طلاب المرحلة الثانوية. مجلة القراءة

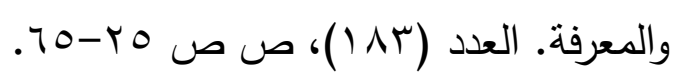
- - علي خطاب( ( . . . .القياس والتقويم في العلوم النفسية والتزبوية والاجتماعية. القاهرة: مكتبة الأنجلو المصرية. - مجدي عبد النبي هلال وآخرون (T ا • (ץ). تصور مقترح للأنشطة التربوية الحرة لطلاب المرحلة الثانوية في ضوء احتياجاتهم العمرية. القاهرة: المركز القومي للبحوث التربوية والتتمية. - محمود جلال الدين سليمان(9 . . ب). فاعلية استخدام مدخل عمليات الكتابة في تتمية مهارات الأداء الكتابي لطلاب المرحلة الثانوية.مجلة دراسات في المناهج

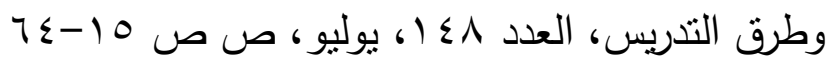


- محمود هلال عبد الباسط(§ ( ب). برنامج مقترح قائم على التعلم المستتد إلى الدماغ لتتمية مهارات الكتابة الإقناعية وأثزه في الحس اللغوي لدى طلاب شعبة

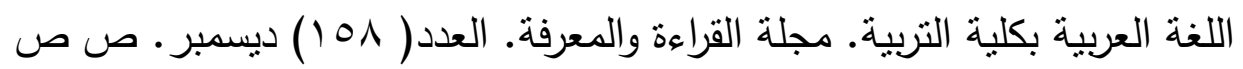
.Ar-Y

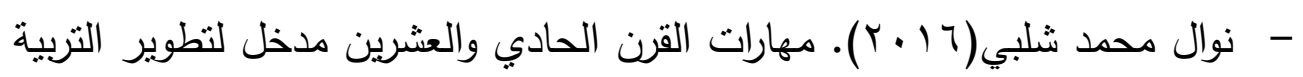
العلمية.القاهرة: نيو لينك للنشر والتدريب.

- نورا محمد زهران( 0 ( ب).برنامج قائم على التعلم الاستقصائي لتتمية مهارات لـات الكتابة الإقناعية وبعض عادات العقل لدى طلاب المرحلة الثانوية. رسالة دكتوراه. غير منشورة. كلية البنات للآداب والعلوم والتربية.

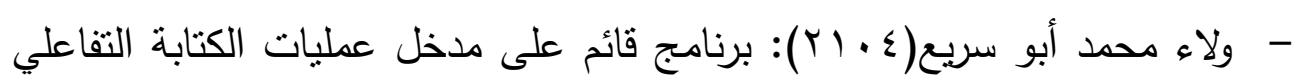
لتتمية مهارات الكتابة الإقناعية لدى طلاب المرحلة الثانوية. رسالة ماجستير (غير منشورة) كلية التربية. جامعة عين شمس.

- Abdul Aziza,F.,\& Ahmad.U.,(2017): Persuasive Writing: How Students Argue., Journal of Sains Humanika, (9), 4-2, 19- 32 .

- Beyreli, L. \& Konuk, S. (2018). A Research on The Improvement of Persuasive Writing Skill of Sixth Grade Students in Secondary School. TED EĞİTİM VE BİLİM. 43. 10.15390/EB.2018.7520. Essays. Pennsylvania. Centre of the study guides $\&$ strategies.

- Broussard, S. C., \& Garrison, M. E. B. (2004). The relationship between classroom motivation and academic achievement in elementary school-aged children. Family and Consumer Sciences Research Journal, 33(2), 106-120. 
- Center on Education Policy (2012 ). What is motivation and why does it matter? The George Washington University Graduate School of Education and Human Developmen.

- Driver, R.; Newton P., \& Osborne, J.,(2000): Establishing the norms of scientific argumentation in classrooms, Science Education Journal, vol. (84), No.(3), PP.(287-312), John Wiley \& Sons press, U.K., 2000.

- Farous I., A. \& Ummul, A. (2017). Persuasive Writing: How Students Argue. Sains Humanika. 9. 10.11113/sh.v9n42.1356

- Guay, F., Chanal, J., Ratelle, C. F., Marsh, H. W., Larose, S., \& Boivin, M. (2010). Intrinsic, identified, and controlled types of motivation for school subjects in young elementary school children. British Journal of Educational Psychology, 80(4), 711-735.

- Gusdorf, G., (2000):Speaking, published in French under the Title (la Parole) in 1953, translation copy right reserved to Northwestern university Press, 3ed Ed, U. S. A.

- Irish, R. K. (2003). The Uses of Toulmin: The Value of An Explicit Model Of Argument For Academic And Working Engineers. IEEE International Professional Communication Conference. IEEE International, 48-55.

- Johnson, R., (2005):Theory and Practice Again: Challenges from Toulmin and Pinto, In the Uses of Argument: Proceedings of a Conference at McMaster University, David 
Hitchcock Ed, Ontario Society for the Study of Argumentation OSSA, University of Windsor press, Canada. 222-231.

- Johnson, T. S., Thompson, L., Smagorinsky, P., \& Fry, P. G. (2012). To Teach The Five-Paragraph Theme Learning. Research in the Teaching of English, 38(2), 136- 176.

- Kuhn, D., \& Udell, W. (2003). The development of argument skills. Child Development, Qctober, (74) 5 , 1245-1260.

- León, J.,(2011): Justice, Prejudice, and the Basis for Reasonable Legal Argument: The Karen Atala Case, Cogency Journal (Journal of Reasoning and Argumentation), Diego Portales University press, Santiago-U.S.A, Summer.(3) 2, 125-145,

- Martin. L., (2016). Retrieved on 14 $4^{\text {th }}$ April 2019 from :Motivation. from:. https://www.researchgate.net/publication/317371123_ Motivation.

- Nippold, M., Ward-Lonergan, J. \& Fanning, J. (2005). Persuasive writing in children, adolescents, and adults: a study of syntactic, semantic, and pragmatic development. Language, speech, and hearing services in schools. Press, Cambridge, 36. 125-38..

- Nystrand M. \& Graff, N(2001) : Report in argument's clothing An ecological erspective on writing instruction in a seventh grade class- room. 
- Ramage, J. Bean,J.C.\& Johnson, J.(2001).Writing arguments.Mass: Ally \& Bacon.

- Seyler, D.U. (2002). Understanding arguments: A text with readings. New York: McGraw-Hill Inc.

- Tippett,ch.,(2009):Argumentaion:the language of science.journal of elementary science education,21(1),1725.

- Toulmin,S., (2003). The Uses of Argument. (Updated ed.). Cambridge University.

- Udell.W(2007):Enhancing adolescent girls' argument skills in reasoning about personal and non-personal decision. Cognitive Development (22) 3, 341-352

- Voss, F. J.,(2005): Toulmin's Model and the Solving of IIIStructured Problems, Argumentation Journal,. Springer press. Springer On Line U.S.A., (19), 3, 321-329,

- Walton, D.(2008):Informal Logic: A Pragmatic Approach, 2nd Ed, Cambridge University Press, New York .

- Wingate, U.(2012): 'Argument!' helping students understand what essay writing is about. Journal of English for Academic Purposes.11.

- Tagliberg,L.,(2008):critical reading and critical thinking,universidade Federal desanta catering,published,journal Ilhadodesterro,no pp 141-163.

- Wood, N. V. (2001). Perspectives on argument. (Third Edition). Upper Saddle River, New Jersey: Prentice Hall. 
- Hormazabal, R. D. (2007). Argumentative Writing Strategies And Perceptions Of Writing Academic By EFL College Students, Literaturay Linguistica, 18, 253-282.

- Zainuddin, S. Z.,. \& Rafik-Galea, S. (2016). Effects of Training in the Use of Toulmin's Model On ESL Students' Argumentative Writing And Critical Thinking Ability. Malaysian Journal of Languages and Linguistics (MJLL). 5. 114.10.24200/mjll.vol5iss2pp112 Retrieved on $12^{\text {th }}$ April 2019 from: 